
QL
677.5
B182
1931
BIRDS 


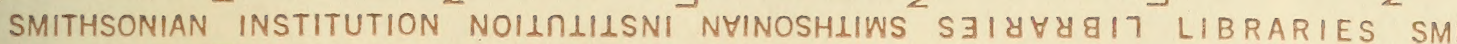
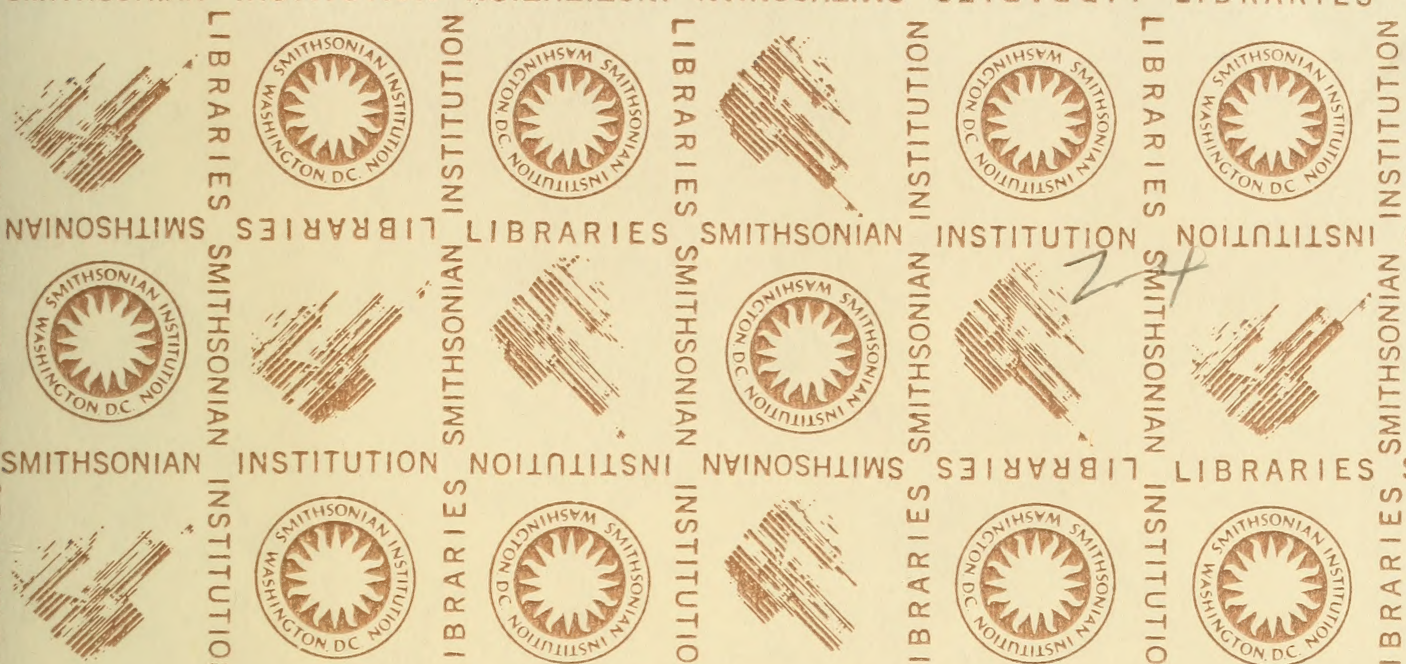

$\frac{-1}{\frac{1}{-1}}$
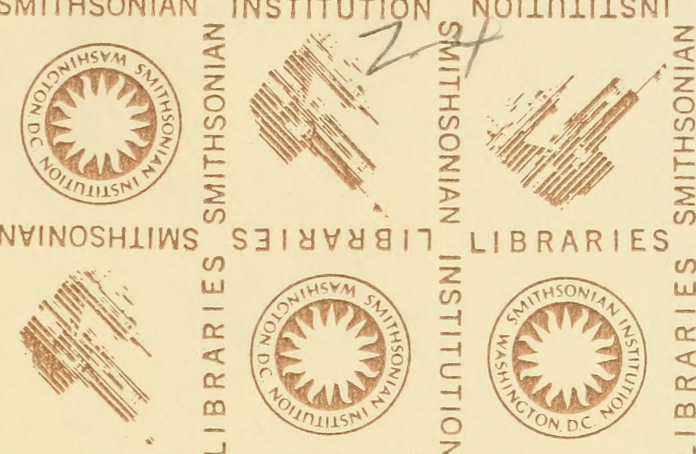

NHINOSHLIWS
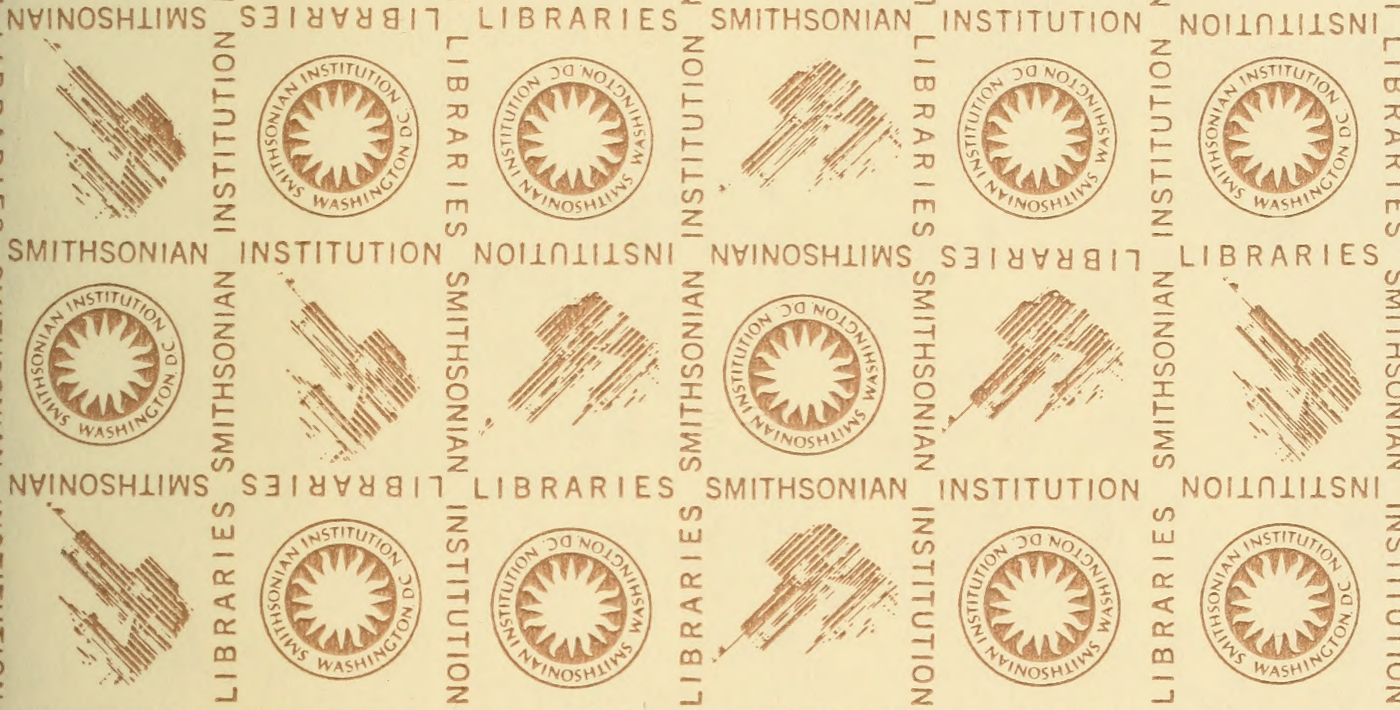

SMITHSONIAN INSTITUTION
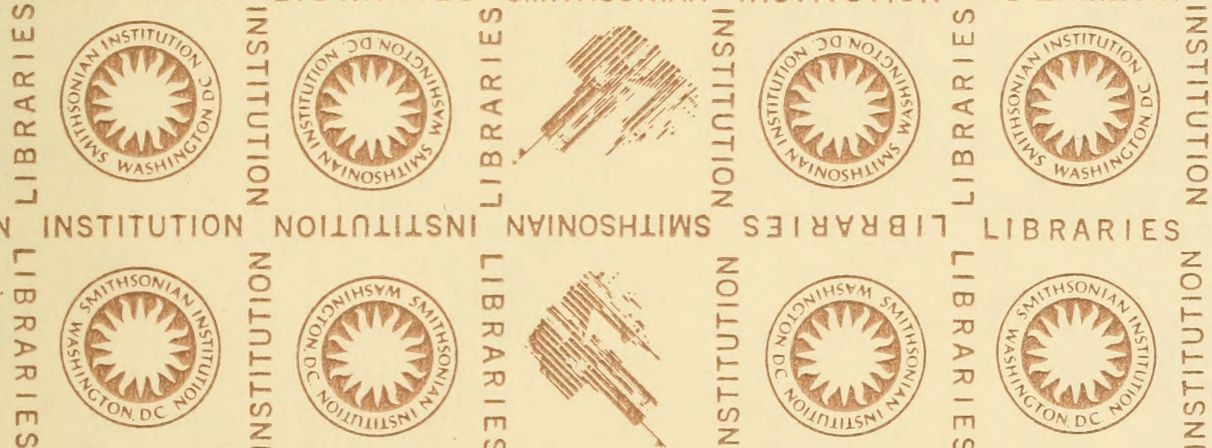

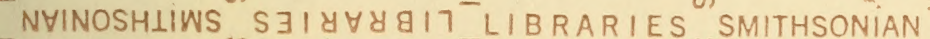
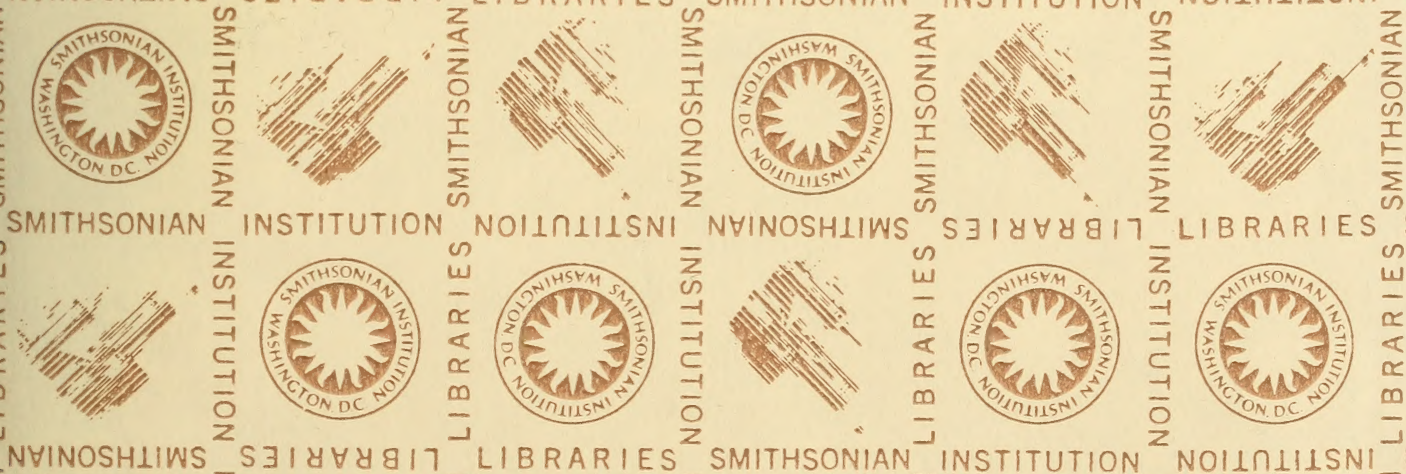

$Q 2$
677.5
Bis 182
1931
Bir BIRD BANDING BY SYSTEMATIC TRAPPING

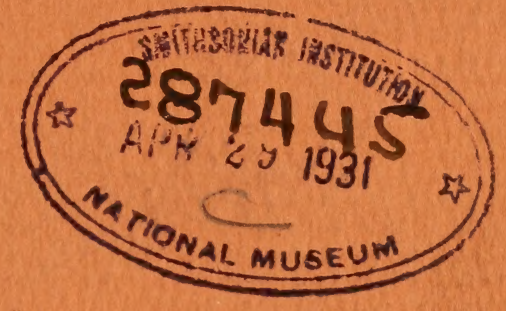

$\mathrm{By}$

S. Prbntiss Baldwin

\author{
SCIENTIFIC PUBLICATIONS \\ OF THE \\ CLEVELAND MUSEUM OF NATURAL HISTORY \\ Vol.I, No.5, pp. 125-168; plates XIX-XXV \\ Issued, April 15, 1931 \\ CLEVELAND, OHIO
}


E.

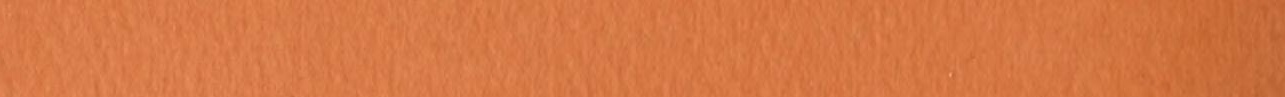

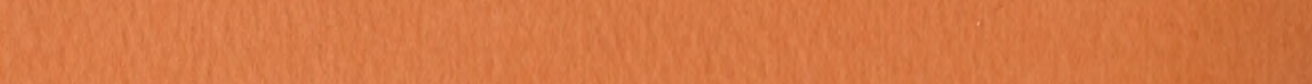

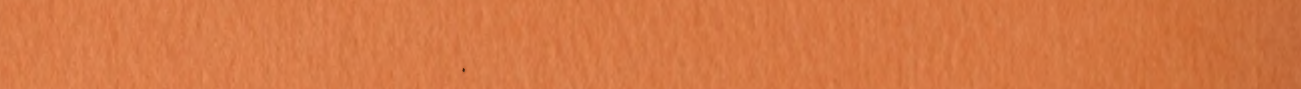

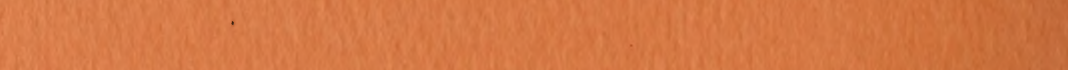

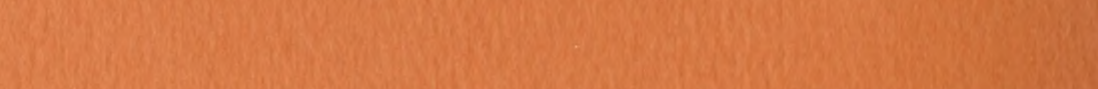
Whate

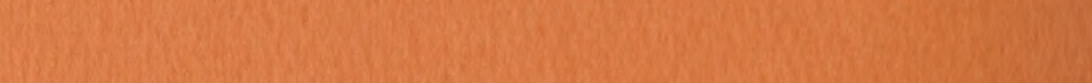

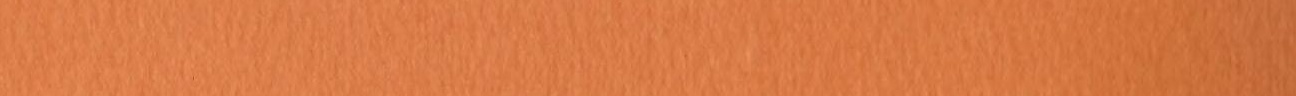
DSW

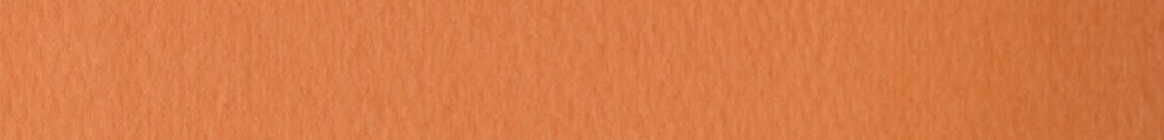
Whe

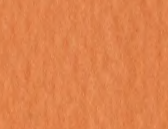
1.13 (a)

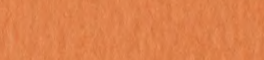

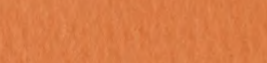

(1)

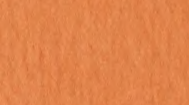

$$
\text { 1.6. }
$$




\section{SCIENTIFIC PUBLICATIONS}

OF THE

CLEVELAND MUSEUM OF NATURAL HISTORY

VoL. I, No. 5

IssUed, APRIL 15, 1931

BIRD BANDING BY/SYSTEMATIC TRAPPING

S. Prentiss Baldwin

\section{INTRODUCTION}

The following pages contain a reprint of two of the author's papers, as follows:

Bird Banding by Means of Systematic Trapping. Abstract of the Proceedings of the Linnaean Society of New York, No. 31, for 19181919 (December 23, 1919), pp. 23-56, pls. I-VII.

The Marriage Relations of the House Wren (Troglodytes a. aedon). The Auk, Vol. XXXVIII, No. 2, April, 1921, pp. 237-244.

The substance of the report published in the first of these articles was given at the thirty-seventh stated meeting of the American Ornithologists' Union, held in the American Museum of Natural History of New York on November 11, 1919. The presentation of this paper at that November meeting in 1919 was, in the early part of 1920 , followed by the adoption of the bird banding method by the United States Biological Survey, and this text was used by the Biological Survey as the first instruction book on this subject.

This method of study is now so extensively used that the Report of the United States Biological Survey for the year ending June 30, 1930, states that there were then 1750 bird banders, that these had placed during the year 182263 bands, and that the return records of banded birds had numbered about 10000 for that year.

The first publication here reprinted was issued at the beginning

\footnotetext{
1 Contribution No. 19 from the Baldwin Bird Research Laboratory, Gates Mills, Ohio.
} 
of this bird banding activity, has long been out of print, and consequently has not been available to many of those at present engaged in bird banding work. To meet the demand for copies of it, the present reprint seems desirable. The other article here republished has also long been unavailable except in The Auk, and owing to its special connection with the early bird banding operations, seems also worth being reproduced.

These papers are now published as a part of Volume I of the Scientific Publications of the Cleveland Museum of Natural History, and are repaged in this volume. The original pagination is, however, strictly preserved, and for convenience of reference the original page or plate number is given in brackets at the foot of each page. A few corrections have been made in the text. 
Apr.

1931

BALDWIN-Bird BANDING BY TRAPPING

127

BIRD BANDING BY MEANS OF SYSTEMATIC TRAPPING

By S. Prentiss Baldwin

With Photographs by A. W. Moller, Thomasville, Ga., and the Author

About the year 1913 I began a diligent campaign against the House Sparrow, on my farm, at Gates Mills, near Cleveland, Ohio, using the so-called Government Sparrow Trap, which catches the birds alive and unharmed.

The Sparrows were destroyed in large numbers, and the farm pretty well cleared of them, greatly to the comfort, evidently, of the native birds; for it was very noticeable that, as the Sparrows decreased in number, the native birds greatly increased. The result was most satisfactory, and the traps should be recommended to all who are interested in attracting native birds to their vicinity.

But, it was when I learned of the American Bird Banding Association that the traps acquired a new and much greater significance, for, as the House Sparrows decreased, the traps became the resort of various kinds of native birds.

In the spring of 1914 I began placing bands, not only upon young birds in the nest, but upon many adults secured from the traps, and by 1915 it became evident that this could be done on a large scale, and with most interesting results in returned birds.

Probably some members of the Banding Association have been discouraged from banding young birds in the nest, when, season after season, they get few reports from their birds; and it has seemed to me that banding, itself, has failed to attain proper recognition, from ornithologists, because the results were necessarily few and scattering.

Much greater returns from trapping: During the last four years I have placed nearly sixteen hundred bands, and, during that time, I have received, from outside sources, only three reports; one, a Robin, banded in Ohio and taken in South 
Carolina; one, a Sparrow Hawk, taken fifteen miles away from where it was banded; and one, a Flicker, taken two miles distant. But, during that time I have retaken by trap, from one year to another, more than sixty birds, and some of those have been taken not only the second, but also the third and fourth years. In five weeks, in Thomasville, Georgia, in 1917, I recorded 25 birds from 1916 and six from 1915.

Birds not frigbtened away by the trapping; "Repeats": The birds regard the trap as a special feeding table, and come to it day after day. I have released the same bird three times in one hour; I have frequently released the same bird four or five times in one day; and I coined the word "repeats" to distinguish, in my notes, these birds from "new." "Repeats" are so numerous that of nearly seven hundred birds handled in five weeks, in Georgia, two-thirds were "repeats" and only one-third "new." One Brown Thrasher, on two successive spring seasons in Georgia, spent most of every day in the trap. And a Cardinal became such a nuisance, by getting into the trap and keeping others away, that I moved the trap to another location. In summer one may keep almost daily record of certain Song Sparrows nesting near by, and in migrations one may know the day an individual bird comes, and the day he moves on. One learns to know the characters of certain individuals, as I came to know a certain White-throated Sparrow, who always identified himself by fighting and biting my fingers; and another White-throat, who distinguished himself as a squealer.

How much time or trouble? In presenting the following report, as the result of four or five years' effort, it is only fair to explain how little time and how scattering an effort has been possible to the writer.

The work at Gates Mills, near Cleveland, has been carried on during five summer seasons; but I do not go to the farm until some time in the month of May, or first of June, after all spring migration is over; then by mid-July I am usually gone for an absence of six weeks; and then return to the farm for September and October. This limits the work to six weeks of nesting time in spring, and perhaps two months in 
Apr.

1931

the autumn, at a time when many birds have formed flocks or started southward. Not only is the Ohio work thus limited, but when living on the farm, I am in the city three days a week, so, with stormy days or other things to interfere, I can run the traps only two or three days in a week.

The work at Thomasville, Georgia, has been carried on for only three seasons, 1915, 1916, and 1917. From three to five traps are run on every clear day, and I can give them very regular attention, but my whole season at Thomasville is, usually, only five weeks of February and March.

I explain with so much detail the rigid restrictions under which these observations were made, because I have realized so fully that my best opportunities for steady and consistent observation are repeatedly lost by my long absences.

I urge this upon the bird student who may consider these methods of work, for it is certain that any person who lives all the year in one place, in the country, or on the edge of town, can obtain much greater scientific result with much less effort, than my haphazard work costs me.

While this report includes only the "Returns" of birds taken from one year to another, it is evident that not less important, to a person who operates traps at the same place all of a season, or all of a year, is the opportunity, by this method, of keeping in touch with the daily life of birds living in the vicinity; of knowing just when they come; just when young leave the nest; just how long they remain in the vicinity; and when they leave; and watching the exact movements of individual birds during migration. Indeed, the careful observer, in a fixed location, may obtain facts of greater scientific value on the daily records than from the reports from year to year.

How to trap: Bait the ordinary sparrow-trap with cracked grain and bread. The grain should be ground fine, what is usually sold as the finest or first chick food, and scattered thinly to a distance of five feet from the trap. The soft parts of the bread may be very finely divided by rolling in the hands, but save the crusts and larger pieces and drop them inside the trap. 
My experience shows that a bird has a good eye for the largest piece, and a group of birds, instead of picking up the fine particles outside the trap, will push eagerly into the trap to the large pieces. (See figure 1.)

Bait: Of course, many varieties of birds will not come to a grain and bread diet, though I have been surprised to find such birds as Myrtle and Palm Warblers, and even Redbellied Woodpeckers, coming freely to such a bait. I have drawn Cedar Waxwings with Ligustrum berries, in Georgia, but failed to trap them, probably because of a great abundance of fruit on the bushes near by. Robins we have not taken for lack of proper bait, but, no doubt, they can be taken with some care in the use of mulberries or other fruits, when fruit is not too abundant on the trees.

There is much to be done in providing proper baits to secure other kinds of birds, but I have not had time to experiment in it.

Speaking of baits, the best attraction to draw House Sparrows is to leave a couple of Sparrows in the trap; but I do not leave other birds in the trap, to draw their fellows, because of the danger of injury to a bird remaining in the trap long.

Guard fence: It is absolutely necessary to place a guard fence around each trap to keep the neighbors' pet dogs and cats at a distance. These animals will surely find the trap and torment the captured birds if it is unprotected. A piece of chicken-net fence three feet high, and about 60 feet long, will make a circular pen about 20 feet in diameter, in which to place the trap. (See figure 1.)

Other trapping methods: Of course, many trapping methods are well known, but I wish to call attention to a simple trap door, which may be used on boxes, for Wrens, Bluebirds, and other birds nesting in boxes or holes in trees. (See figure 2.)

A small piece of zinc is so bent upon a piece of wire, that it serves as a perch; the wire is loosely tacked to the box with staples, and is so bent that a thread may be fastened upon the end of the wire. A pull on the thread closes the perch up against the entrance. With a couple of staples this trap 
Apr.

door may be attached temporarily to any box, or tree stump, and used for all the hole-nesting birds.

The time to get these birds is when the young are hatched and both parents are coming frequently to the nest to feed them. It is best to get them before the young are many days old, for the young birds soon are old enough to crowd up to the entrance, and the parents feed them without entering, and so cannot be taken.

Placing of band: Always use the smallest size of band that will close around the leg of the bird, fitting it snugly so there is no room for twigs or thorns to slip through and catch in the band. According to my observation, the legs of young birds are larger, more fleshy and soft than those of adults, so no allowance for growth need be made in banding young birds approximately full grown. In fitting snugly, however, the band should be loose enough, and so shaped as to slide easily up and down the leg without binding.

The Cardinal is the only species that, in my experience, is so strong of beak as to bend or pinch his band, in attempting to remove it, and he will, of course. I use on the Cardinal a large-sized band, that will go twice around the leg and resist pressure of the beak.

$A$ bird in the band: In the handling of many hundreds of birds, one finds certain ways of holding a bird firmly, so that it cannot flutter.

For examination, the bird is best held sitting upright, resting with his claws on the little finger, and with his neck between the first and second fingers. (See figure 3.) In this position the bird will rest placidly, even with the hand left open, so the entire body of the bird may be examined easily. For placing a band, the bird is best held on his back, with the little finger snugly over the throat (see figure 4); and the thumb and first finger are thus in position to hold the leg while the band is adjusted. (See figures 5 and 6.)

$V$ isit the traps often: During the nesting season the traps should be operated only when they may be closely watchedvisited at least every hour to prevent the possibility of keeping parent birds from the nest when eggs or young need attention. 
At other times, one may visit the traps only four or five times a day, or leave them for some hours, but at some risk of injury to the imprisoned birds.

The entrance wires of these traps may be adjusted to admit larger birds, or set closely enough to the ground to admit only smaller ones. I have caught Catbirds, Brown Thrashers, Blue Jays, and even Doves, but when the entrance is set high for these birds, the smaller birds will learn to run in and out of the trap without being caught. The first hours of early morning, daybreak, are most fruitful, for all birds hunt a breakfast soon after they wake in the morning. The traps should, therefore, be set and baited the night before. An early morning visit is wise, however, as I have sometimes found a whole family of rats in the trap as an over-night product.

The traps should be visited just at dusk, or after all the birds have gone to roost, for a bird is sure to suffer cold, or storm, or injury by mammals, if left over night in the trap.

Injuries: In considering the possible injury to an occasional individual bird by reason of the trapping, it must be asked by what other method may one study, actually in the hand, hundreds, or thousands, of native birds, with so little harm to them? Of some five thousand or more birds that I have held in my hand, during the last four years, not two dozen have been killed. And shrikes have been the cause of most of the fatalities, so that actually not five birds, or one in a thousand, have been killed by the trap or by my carelessness.

One bird was left in the trap over night, a night of storm, and became chilled, and died. Who can tell how all the birds protect themselves so well from storm and come out smooth and dry immediately after? They come out like wet dish rags if caught by a rain in the trap. One warbler was killed when I set the gathering cage down, when his head was pushed out through the mesh at the bottom of the cage. One must watch that carefully.

Many birds in their efforts to escape from the trap scratch the forehead just above the bill, and sometimes scratch it enough to bleed, but this seems to be a necessary incident to 


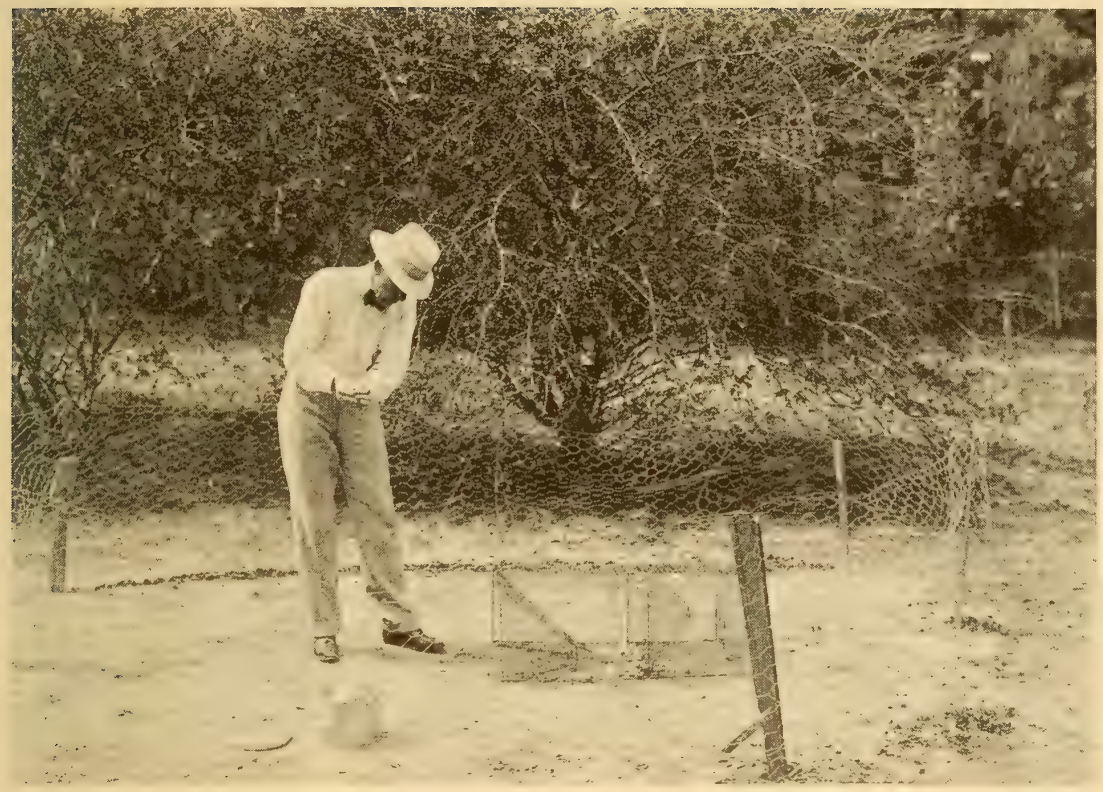

Fig. 1.-Scattering Bait at Station C, Thomasville, Georgia. (See page [26].)

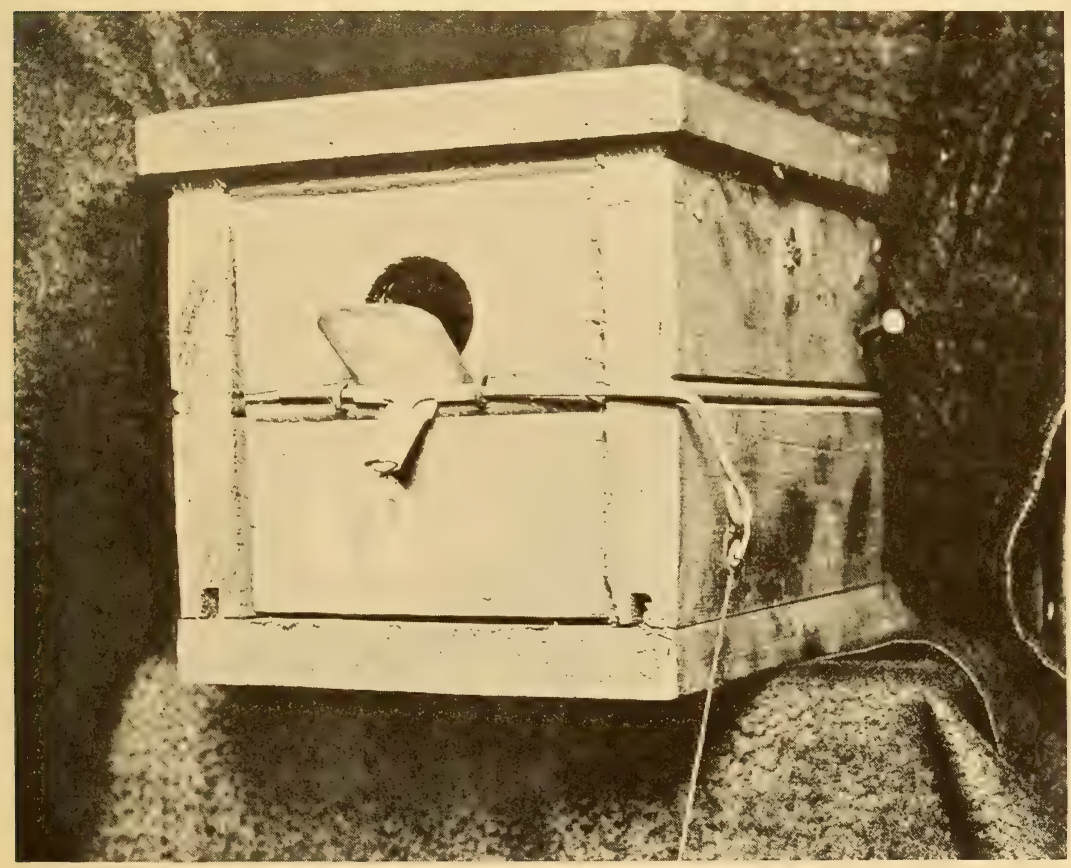

Fig. 2.-Perch Trap Door (Partly Closed), in Use on a Bluebird Box. (See page [26].) 


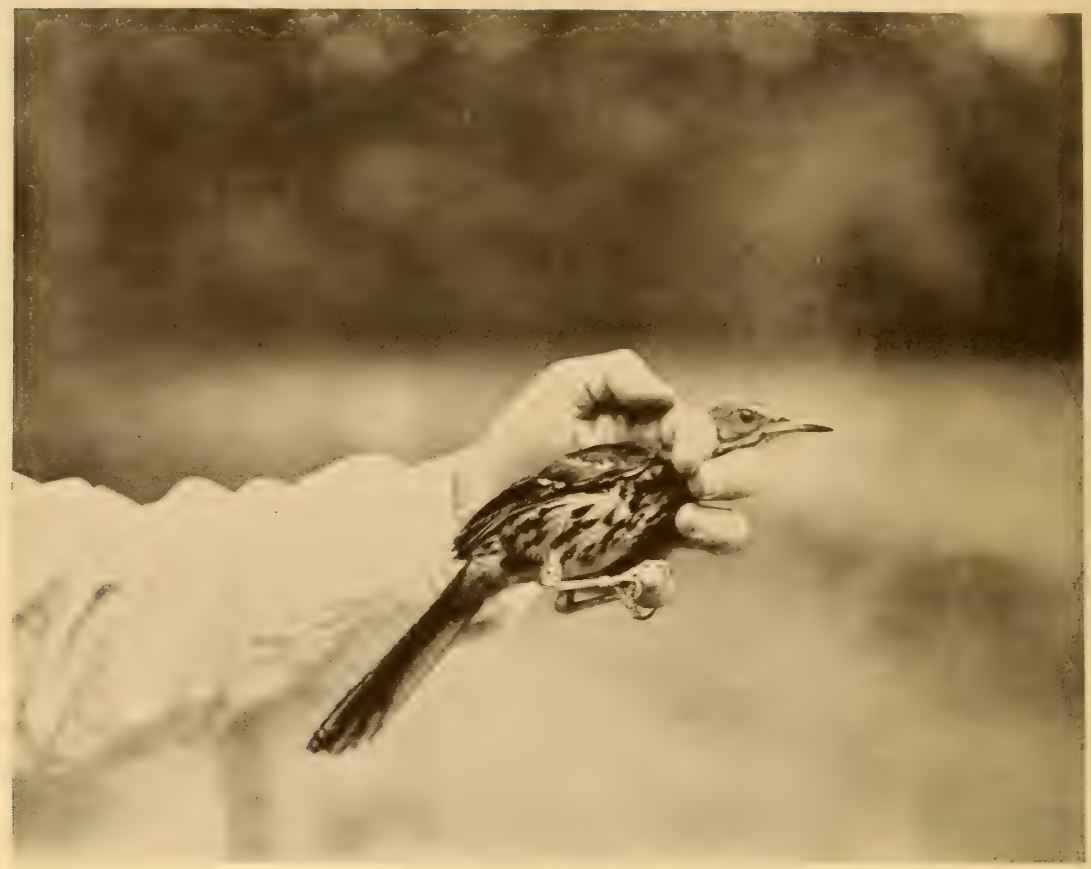

Fig. 3.-Brown Thrasher, Showing Method of Holding for Examination. No. 40222. (See page [27].)

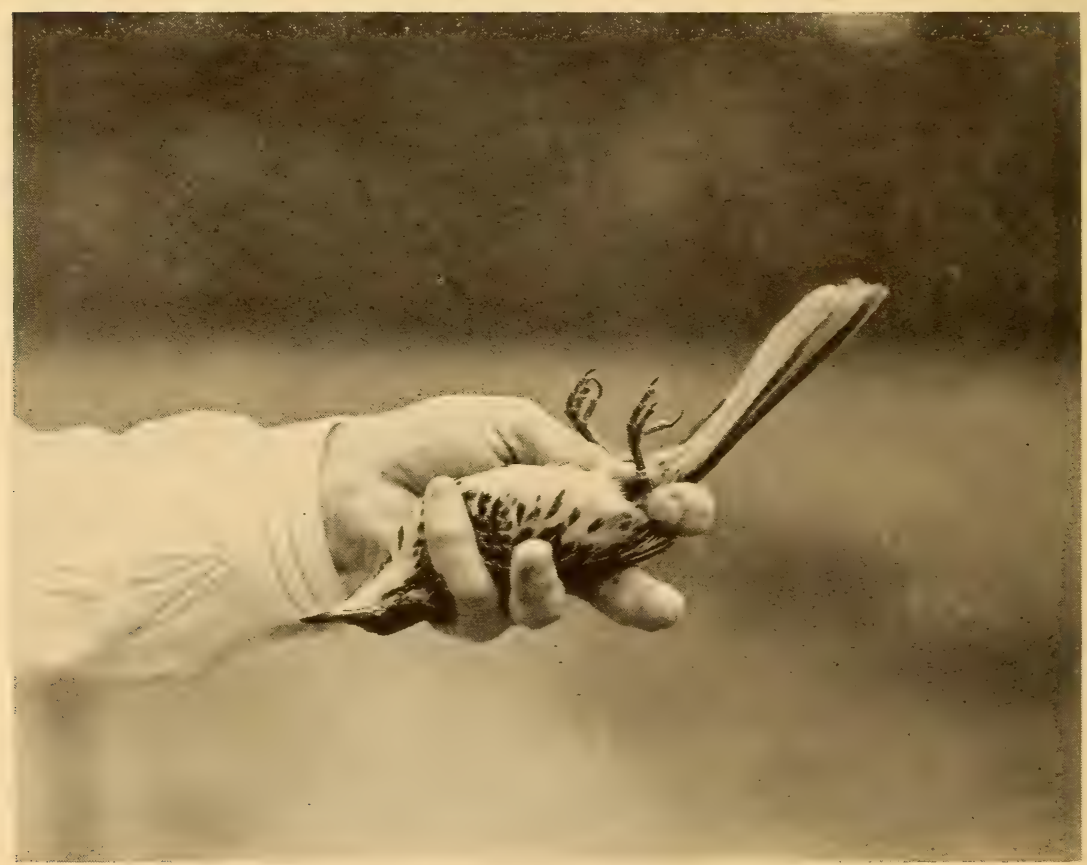

Fig. 4.-Brown Thrasher, Showing Method of Holding for Placing a Band. No. 40222 . (See page [27].)

[II] 
Apr.

trapping, and not more serious than a scratched finger to a man. These scratched heads are completely healed in three or four days, as I have had proofs many, many times.

The one really serious danger of injury is that a cat, or one of the small hawks, or a shrike learn to get at the trap, and infest the spot until destroyed. I have had little of this trouble in Ohio; but the Loggerhead Shrike is so numerous and destructive in Georgia, that at first sign of torn or injured birds, diligent search must be made for one. These raiders have repeatedly followed their prey into my traps, killed the small birds, and then, being themselves caught, suffered the just penalty for their murders. I do not know what the official judgment is upon the shrike, but to me it appears, in the South at least, very destructive to small birds, and it should be systematically destroyed.

Home record system: In a small box which fits in my pocket, or in the feed pail, I carry the bands, pincers, and pencil, also a "day card" as I call it, a card, of the size used in card systems, upon which I enter every bird taken that day, just the number, name, and trap location, as I keep a record of which trap a bird is taken from. Then each day these entries are posted into a card system, such as that kept by the Banding Association, this being my permanent record. As the entries of the day cards are posted back through the card system, one really establishes a ledger account with each bird, so that his card shows at all times all the different visits he has made to the traps, and the card contains, in fact, a continuous history of the individual. (See day card, figure 11.)

A very handy reference, convenient to use in the field, to find back numbers of re-taken birds, can be made by taking off, upon a few typewritten sheets, the completed season's records. And this condensed tabulation gives a more comprehensive view of the entire season, than one may obtain from examining a card system.

Law: While it is not probable that the game or bird protective organizations in any state would seek to interfere with the scientific study of birds by this method, yet it is possible that the taking of native birds, even for prompt 
release, may constitute a technical violation of the State Law. In some states it might happen that a local official, either in spirit of revenge, or in too great avidity for fees, would seek to take advantage of such technical violation.

It is well, therefore, to take up the question with the authorities and to secure perhaps a collector's permit.

Consider also the Federal Migratory Bird Law.

The feeding and protection, that are much a part of this work, so greatly overbalance any occasional injury caused, that this form of study should have every encouragement.

What we may bope to learn by banding: This question is asked many times, and it may be suggestive to others to point out some of the questions for solution.

1. How long do native birds live? Many returns will, in the course of time, give cumulative evidence as to this point.

2. Birds do return to the same spot for nesting year after year. The American Bird Banding Association has a great number of proofs of this, besides the proofs appearing in this report.

3. Birds do return to the same spot to spend the winter year after year. This report gives ample proof of this fact.

4. Not only are these two propositions true, but the returns contained herein prove that, in migrating, birds stop off at the same feeding places along the route.

5. Where several traps are operated not far from one another, we may obtain some idea of how far birds wander in their feeding, or to what extent do they come to the same feeding table, day after day.

6. My experience is that migrants do not travel each day and about the same distance each day, as some suppose, but, on the contrary, they linger at places along the route, where the feed is good, and while weather is suitable. On route to the South, the next storm will remind them of approaching winter and off they go. I have not been able to determine whether they move ahead of the storm or during the storm, but they are likely to be gone the morning after.

7. If birds do come back to the same place to nest year 
Apr.

after year, will they use the same nest box, and retain the same mate? In my work I keep exact record of the tree or box used by each bird for nesting, and of the trap location where one is taken each time.

8. My experience indicates that when the young birds leave the nest, the family usually does not linger near by, but moves at once away from the locality. A pair of Wrens moved their family of six young, three hundred yards across my place, during the first day out of the nest, and toward night, had all six lined up in a row on the top wire of a fence.

9. To what extent do birds raise the second brood in the same nest, or same vicinity as the first brood?

10. We may hope that if birds come back to the same spot to nest we may keep a faithful genealogical tree of an individual with its mates and young, from year to year. This seems a joke until you read the history of numbers 27739 and 27740 as given herein.

11. Do young birds return to the same spot another season? I have two cases, a Song Sparrow, Number 44018 banded July 4, 1917, and taken June 23, 1918. And just this week, March 19, 1919, I have taken a Robin, banded as a young bird in the nest May 15, 1917, No. 32932.

This report alone is enough to prove that they do return, not only to the same spot for summer for nesting, but to the same spot to spend the winter. The scientist, rightly agnostic as to it, must have the fact of return proved, and it is amply proved.

But the popular opinion altogether too readily accepts each pair of any species that nests near last year's nest, or in the last year's hole or box, as the identical individuals that were there last year. I have had, frequently, pointed out to me, the same pair of birds that, according to my informant, have nested on the same porch pillar for many years.

While my evidence does not go so far as to call it positive proof, yet my experience is that, in such cases, the chances may be one in five that one of the pair may be the same individual, and, perhaps, the chances are one in twenty-five that both individuals may be the same. 
This does seem discouraging to our ideals of the same old friends coming back to our shelter so many years, but the truth is interesting enough to be worth while.

To illustrate the point: In 1915 I banded 44 Wrens, every Wren on my place, old or young. In 1916 there were six adults on the place, only two of which I secured and one was from 1915.

More to the point, in 1917 I banded 23 Wrens, old and young, on the place; and in 1918 I caught 9 adults, every adult I saw, and only one of the nine was from 1917.

An interesting illustration of the popular opinion occurs in the report of Sparrow Hawk 21531, where Mr. Haylor, an unusually intelligent observer, says, "For the last few years this same Hawk, so we think, has sat on the tip of a church steeple for hours, each day." The Hawk was, in fact, at that time only fourteen months old.

\section{Banding at Thomasville, Georgia}

Season of 1915

Two traps were operated, about 200 yards apart, during one month, from February 26 to March 28.

Total birds banded during the month....................90

Of these I classified as migrants .........................

residents........................ 27

In this classification I have considered as undoubted migrants the White-throated Sparrow, Chipping Sparrow, and all Warblers; as probable all-year residents, Carolina Wren, Towhee, Cardinal, Brown Thrasher, and Blue Jay, though I do not mean to imply that any individual of these may not be in fact a migrant. The presumption in favor of permanence of these birds consists in the fact that they appear, in March, to be settled as to locality, in pairs, mated, and nesting, and in case of the Thrasher at least, the eggs are laid by that time.

Within a week after placing the traps I noticed the disposition of certain individuals, either migrants or residents, to come back to the traps day after day and, sometimes, two or three times in one day. 
Apr.

1931

15053, White-tbroated Sparrow: Made itself known by appearing in the trap every day and several times a day until I gave up the count of its appearance. This bird always identified itself, in removal from the trap, by savagely fighting the hands, a fact which was especially noticeable because the other eleven, of the total twelve White-throated Sparrows banded, showed no such fighting spirit at all. This bird is of interest also for being taken again in the same spot in 1916.

16486, Cardinal (female): Was conspicuous for the trap habit, coming to the trap for all her meals and being released several times a day, until I moved the trap 100 yards in order to be free from her.

19246, Brown Thrasher: Living under our bed-room window, at once formed the trap habit, and was released, often several times a day, until it learned not to flutter upon my approach, but to stand quietly at the door waiting for it to be opened!

19247, Brown Thrasher: Mate of 19246, but, while coming often to the trap, it was always shy of entering and was taken only twice, February 27 and March 13.

\section{Season of 1916, Thomasville}

During this active banding season of less than six weeks, from February 19 to March 30, two traps were operated, but four locations were used, the traps being moved from day to day.

These locations were about 100 yards apart, strung across open fields, mostly surrounded by pine woods; they were mostly near buildings and shrubberies and were always kept baited, whether the trap was present or not.

Total birds taken from two traps. . . . . . . . . . . . . . . . 654

Of this number, retaken or repeats . . . . . . . . . . . . . . . . 441

New birds banded ................................ 213

1915 birds taken in 1916, residents,

1915 birds taken in 1916, migrants,

8 from a possible 27

Of 213 new birds, migrants were......................... 169

residents were. . . . . . . . . . . . . . . 44

"Retaken" or "Repeats": I have applied the term "Repeats" to those birds which come into the traps, some of them 
again and again, after they first receive a band. The great extent to which they return to the traps will be seen from the above number (441) of repeats out of a total 654 birds removed from the traps. This will be further appreciated when I say that more than half (115 individuals) of the 213 new birds were taken a second time or oftener, in the month, while some individuals form the "habit," and are taken every day or several times a day.

Daily record of traps: A tabulation of daily records shows only a very dull season from February 19 to March 7 of only 4 to 6 total birds per day from the two traps, perhaps half being new birds. Then there was a sudden jump on March 8 to total 14 . On March 9, total 29 birds; with varying totals up to 65 birds on March 13, and 75 on the 15th; averaging usually about one-third new. The sudden jump to high daily records came when the Myrtle Warblers and Chipping Sparrows began suddenly to come in great numbers; chiefly Warblers at first about March 8, then chiefly Chipping Sparrows after March 13.

Limits of range: At Thomasville, in 1916, I have faithfully kept a record of the exact location where each bird is taken, each time, this by lettering the stations and attaching the letter each time with the date a bird is taken.

With the four Stations, "A," "B," "C," and "D," 100 yards apart, in a line, making a total length of field some 300 to 400 yards, it is interesting to note in retaking Brown Thrashers 28 times, only two were retaken as far away as the next Station. White-throated Sparrows never occurred except at Station A. Towhees retaken ten times were never so far away as the next Station. Blue Jays had wandered to the next Station in two of the cases out of four, Woodpeckers had strayed to the next Station in three cases out of six. In case of the flocks of Myrtle Warblers and Chipping Sparrows, we might expect more wandering, yet only a third of those retaken were so far away as the next Station (on a count of 150 cases). 
Apr.

1931

We must bear in mind that the birds would wander further in search of a scattered natural food, than under these artificial conditions where plenty is always to be found at one spot, or rather at four spots or stations; yet, making all allowances, these figures show what to me seems a surprising limit of foraging range; the Thrashers, Towhees, and White-throats within a 100-yard radius; Blue Jays and Woodpeckers further but within 200 yards; and, perhaps more interesting, the fact that the Warblers and Chipping Sparrows, migrants in flocks, come day after day to the same feeding station to such an extent. In fact, these migrants do not wander about carelessly over a wide area, but settle down where food is good and stay there.

\section{Returns in 1916 at Thomasville}

These classed as Residents:

19246, Brown Thrasher (Toxostoma rufum):

1915. Banded February 27, then taken on March 13 and two or three times a day every day until the trap was moved on March 23, always at Station A.

1916. Taken February 21, 22, 25, 27, 28, and March 1, $2,16,29$.

This bird had the trap habit last year - came for all his meals, became very tame, waiting always patiently at the door to be let out; appeared promptly this year in exactly the same spot, the second day the trap was put out, February 21 , and at once fell into the same habit of constantly visiting the trap.

Not taken in 1917 although the mate 19247 was taken then. 19247, Brown Thrasher:

1915. Banded February 27 and taken also March 13; mate of 19246 always at Station A.

1916. Taken on March 4, 11, and 17. Mate of 19246 this year also. 
This bird was quite shy of the trap both last year and this year but came regularly to the trap with 19246, remaining usually outside while 19246 would go promptly inside.

1917. Taken March 11 with 31783 , probably the mate of this year. 19246, its former mate, was not found in 1917. Taken alone also March 12 and 13 .

19252, Brown Thrasher:

1915. Banded March 18 and taken again March 25.

1916. Taken February 28.

17268, Brown Thrasher:

1915. Banded March 12 and taken again March 25.

1917. Taken March 28 and 29.

19248, Blue Jay (Cyanocitta cristata cristata):

1915. Banded March 16.

1916. Taken March 9 at B Station, 27th at A Station.

1917. Taken March 10 at A Station.

19254, Blue Jay:

1915. Banded March 20.

1916. Taken February 28.

19670, Cardinal (female) (Cardinalis cardinalis cardinalis):

1915. Banded March 24 with 1-a size band.

On March 28 I removed the 1-a size band and placed a No. 2 size.

1916. Taken March 26 and 29 and band found in good condition. This bird always at Station C.

15099, Carolina Wren (Thryotborus ludovicianus ludovicianus):

1915. Banded March 18 with its mate 15100.

1916. Killed by a cat March 14 at the same Station (D) where it was banded last year.

These are classed as Migrants, and the White-throated Sparrows and Myrtle Warblers must be supposed to have 


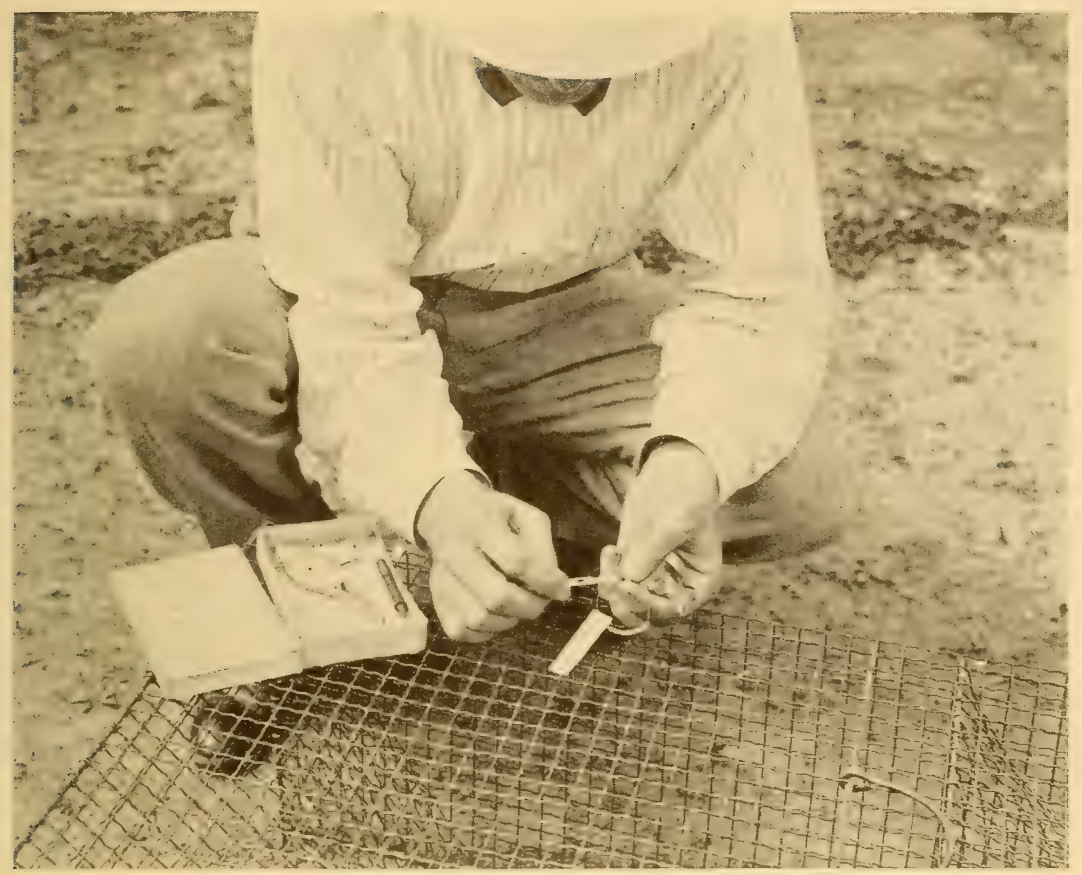

Fig. 5.-Holding a Bird While Opening a Band with a Small, Tapering Instrument Before Placing the Band on the Bird's Foot. (See page [27].)

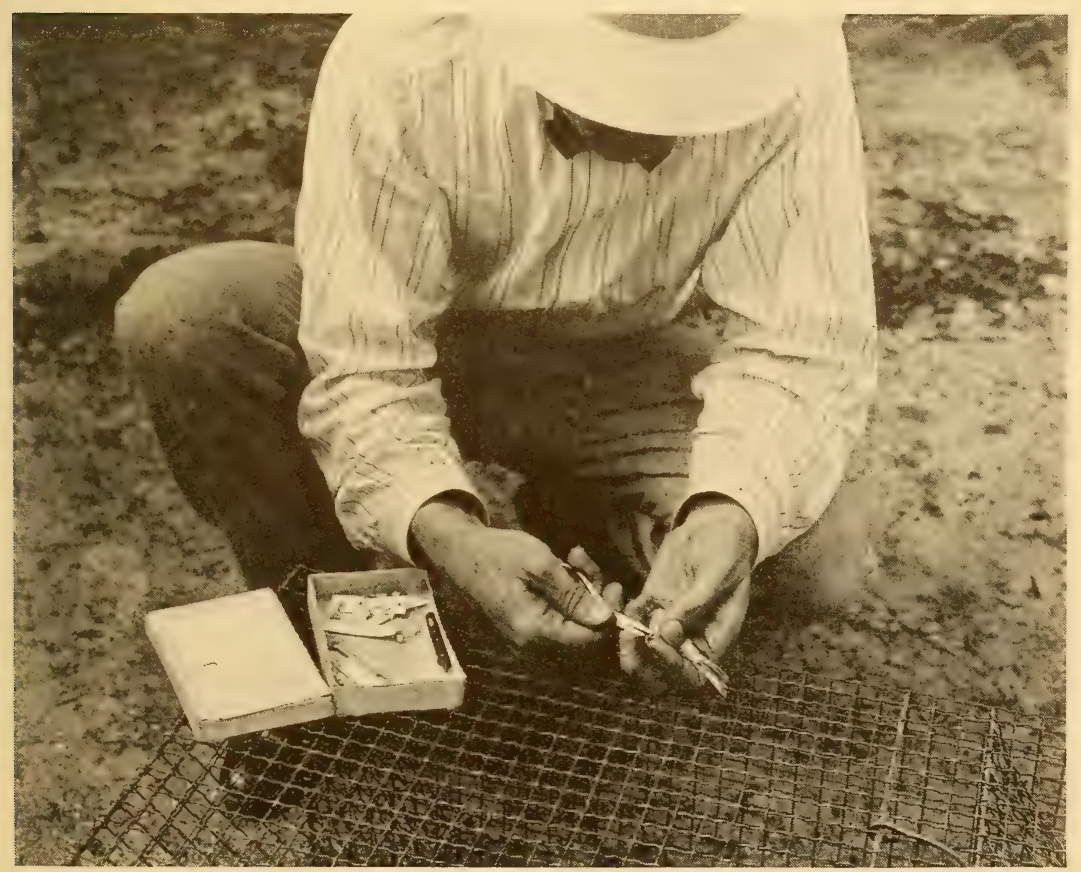

Fig. 6.-Pinching a Band Together over a Bird's Foot. (See page [27].) 



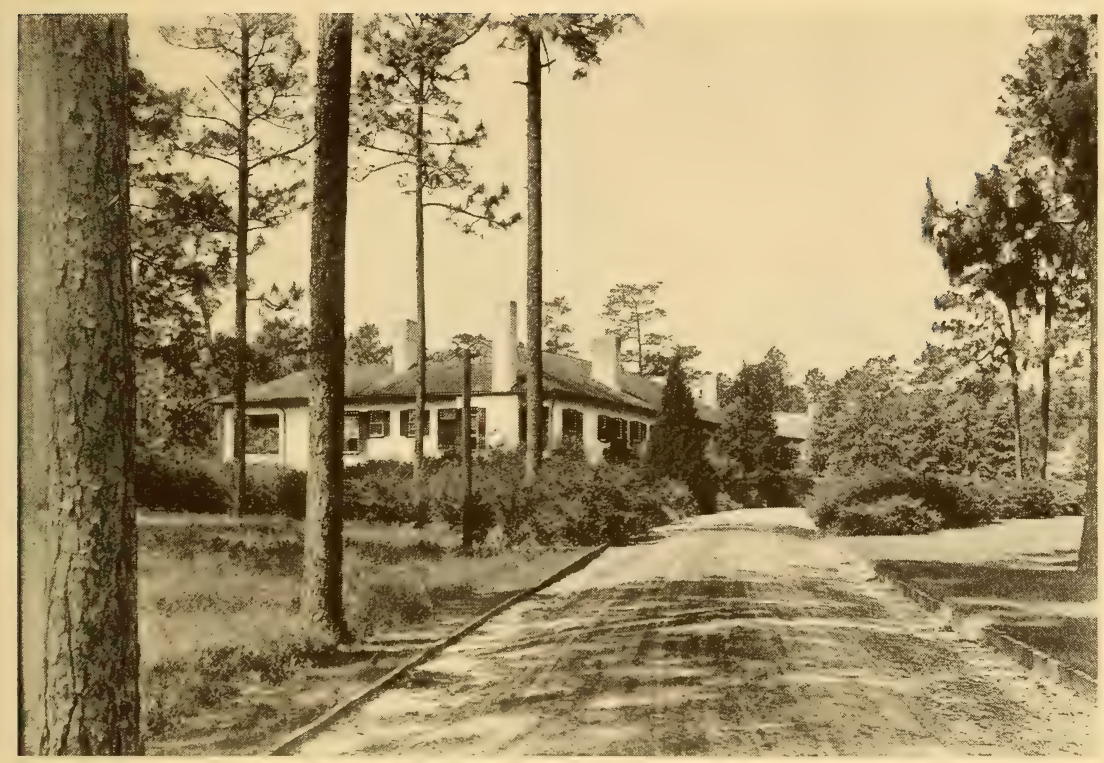

Fig. 7.-Station A, Thomasville, Georgia. (See page [37].)

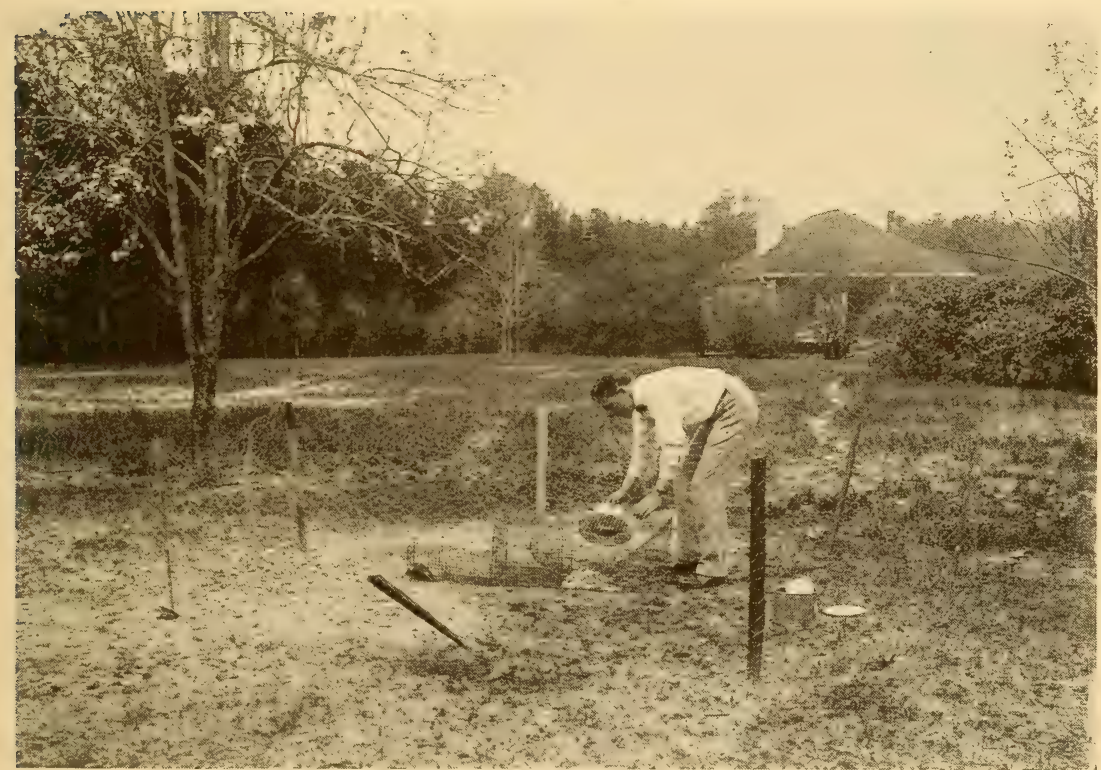

Fig. 8.- Station B, Thomasville, Georgia. (See page [37].) Driving a Dozen Chipping Sparrows prom the Trap into the Gathering Cage. 

Apr.

1931

spent the summer of 1915 in Canada, or, at least, far north in the United States.

15053, White-throated Sparrow (Zonotrichia albicollis):

1915. Banded February 27 and taken many times between that date and March 23, and always identified itself by fighting and biting the hand savagely.

1916. Taken March 1 and 11.

15058, White-throated Sparrow:

1915. Banded March 7.

1916. Taken March 28.

15076, Myrtle Warbler (Dendroica coronata):

1915. Banded March 26.

1916. Taken March 8.

17299, Chipping Sparrow (Spizella passerina passerina):

1915. Banded March 27.

1916. Taken March 13, Station C.

38325, Chipping Sparrow:

(Former number 15096).

1915. Banded March 18.

1916. Taken March 13.

The leg was found to be injured by pressure of the band, so the old band was removed and new band adjusted to the other leg.

\section{Notes at Thomasville, 1916}

White-throated Sparrows: During both years, 1915 and 1916, in February and March, a flock of perhaps twenty have remained constantly in the shrubbery about Station A (see Fig. 7). I marked twelve in 1915, recovered two of these in 1916, and marked five new ones in 1916. These birds were seldom seen as far away as Station B (100 yards) and never caught so far away (see Fig. 8). More could have been marked and perhaps more from last year recovered, but the trap was, in 1916, run at Station A only occasionally. 
Myrtle Warblers: A few were found in flocks about the more open Stations, especially B and C, from February 19, when the traps were first set out, but about March 8 they became more numerous, then by March 20 they were mostly gone. Some individuals, however, remained about the place during the entire five weeks; as 38148 banded February 22 and taken very often to March 23; 38158 taken often from March 4 to 22; 38168 taken often from March 8 to 29; and 38169 taken often from March 8 to 21 .

Chipping Sparrows: First appeared on March 8, and abundant within a day or two; they continued to be taken in quantities up to the end of March, when my observations ended. Curiously, the Chipping Sparrows seem to be notable for defects of the toes, one or the other foot being very commonly swollen or club-footed. None of these cases seemed to be sore or showed signs of recent injury or disease. This effect has not, to my recollection, been seen on any of the many hundreds of birds of other kinds handled during the last two years.

Cardinal: The Cardinal is, no doubt, an all-year resident. In fact, I do not consider the Cardinal anywhere migratory, as it is found in northern Ohio abundantly all winter.

In 1915 I banded a dozen or more Cardinals with size 1-a bands, but as I got them back in the traps I found they had pinched in the bands with their powerful beaks, so as to pinch and harm the leg. 1-a is correct in size, but as I have recovered the birds bearing that size I have replaced the band with a heavier size and doubled the band upon itself to make it still stronger.

The Cardinal fights the hand savagely, squeals loudly in protest when handled and bites with such strength as to be really painful.

Shrikes: The colored people mostly know the "Butcherbird," but by many white people, who are not bird observers, they are mistaken for Mockingbirds. The Butcher-Bird is very numerous in Georgia and must be destroyed where banding by trap is done, for a pair will establish themselves near the trap and follow into it and destroy any small bird that may be caught. 
Apr.

1931

Bait: I have baited uniformly with chick food or finelyground grain and bread.

The Blue Jay, Brown Thrasher, Towhee, Chipping Sparrow, and White-throated Sparrow, Cardinal, Myrtle Warbler, and Red-bellied Woodpecker come freely to that bait; Mockingbirds seldom; and I have taken the Hermit Thrush, Palm Warbler, Pine Warbler, and Carolina Wren.

Healing of injury: Two cases occur of some interest:

38176, Myrtle Warbler: When taken on March 8 was entirely without evident tail, but within a week the tail was quite half-size or more.

31780 and 31779 Brown Thrasher: Were taken in trap together March 10.

31780 was badly torn about the neck and head, and the skin much broken and torn from the rump, with some evidence that it was the result of attack from 31779 while in the trap. The bird was taken on March 12, 15, and 18, and by that time was thoroughly healed and sound, and when taken afterwards, several times up to March 30 , it was quite smooth and healthy in appearance.

Note: Since writing this paragraph in 1916, I have come more and more to believe 31779 not guilty; and that more likely 31780 was injured by the entrance wires of the trap; but I have never found other native birds injured by the entrance wires. Domestic fowls will have their heads caught in the entrance if the guard fence is not kept up.

\section{Season of 1917, Thomasville}

During this season of six weeks from February 13 to March 27 , five traps were operated, at the same four stations (see figures 9 and 10) as in 1916, the stations being about 100 yards apart, and extending a total length of 400 or 500 yards. The whole area is open fields, each station being located by a cottage surrounded by shrubs.

Total birds taken in five traps................... 684

Retaken or repeats......................... 414

New birds . . . . . . . . . . . . . . . . . . . . . . . . . 239 
Return of 1915 birds-migrants

4 from a possible 63 or 6.5 per cent.

residents

2 from a possible 27 or 7.4 per cent.

Return of 1916 birds-migrants

17 from a possible 169 or 10 per cent.

residents

Of new birds banded, migrants were or 18 per cent.

residents. 215

The new birds were as follows:

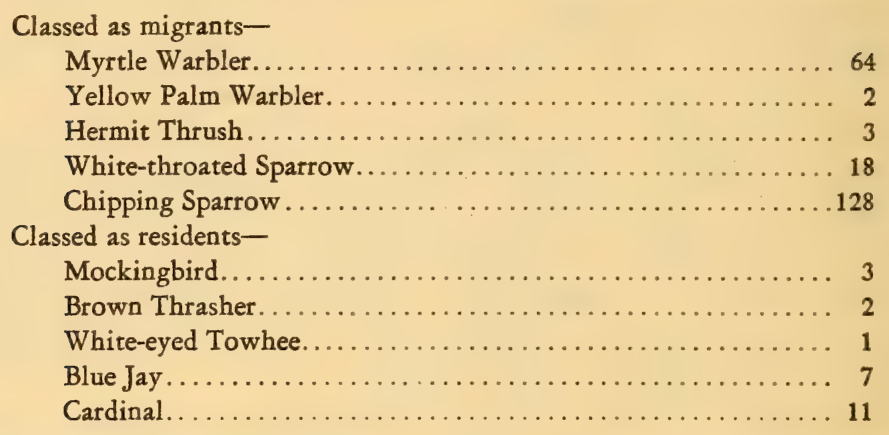

As to Migrants or Residents, we must again state that the division is somewhat arbitrary, being based upon the fact that those birds classed as Residents are at this time mostly in pairs, and some at least nesting.

Among, so-called, Residents we had the following returns:

31766, Mockingbird (Mimus polyglottos polyglottos):

1916. Banded February 20 and taken also March 16.

1917. Taken on February 13 in same trap, Station A.

31773, Red-bellied Woodpecker (Centurus carolinus):

1916. Banded February 27 and taken also March 6, 10 and 26, Stations B and C.

1917. Taken February 21 and March 13, at B and C. 31778, Red-bellied Woodpecker:

1916. Banded March 7 and taken also March 11, 19, 21, 22, and 24, at Stations A, B, and C.

1917. Taken March 9 and 11, at B and C. 
Apr.

1931

31783, Brown Thrasher:

1916. Banded March 11, Station A.

1917. Taken February 25, and March 11 and 21. On March 21 this bird was with 19247, possibly mate, which see, next. Always at Station A.

19247, Brown Thrasher:

Taken in 1915, 1916, and 1917.

See full statement in 1916 list.

40222, Brown Thrasher: (See figures 3 and 4).

1916. Banded March 31, and taken also March 22, 26, $27,29$.

1917. Taken March 3, 6, 8, 15, always at Station C.

31779, Brown Thrasher:

1916. Banded March 10, with 31780, supposed to be its mate.

1917. Taken March 6, leg seemed hurt by the band and the band was removed to the other leg. Taken also March 7 and on March 8 with 40796 and alone on March 15, always at Station D.

19248, Blue Jay:

1915. Banded March 16.

1916. Taken March 9 and 27 at Stations A and B.

1917. Taken March 10, at Station A.

31775, Blue Jay:

1916. Banded March 1 and 4, Station C.

1917. Taken March 20, at Station D.

A very handsome bird.

31770, White-eyed Towhee, male (Pipilo erytbrophthalmus alleni): (See figures 12 and 14).

1916. Banded February 22, and taken also Feb. 25, 28, March 1, 5, 16, 17. Taken with 31771 female on Feb. 25, and with 29843 female March 1.

1917. Taken alone March 9, 11, 13, 15, 16, 19. Taken with 16251 female several times, as follows: Feb. 22, March 12, 14, 15, 17, and on March 
8 taken with a female not marked. Taken always in Trap A except on March 13 in D400 yards distant. It is very unusual to take a bird so far away.

From Migrants we had the following returns:

38168, Myrtle Warbler:

1916. Banded March 8 in B station, and taken March 11 in $B, 12$ th in $D$ and $C, 15$ th in C twice, 17 th in $\mathrm{C}$ twice, 18th in B, 20th in C, 21st in C, 23rd and 25th in C, 28th in C, 29th in C.

1917. This bird resumed immediately the trap habit appearing the first day of trapping February 13 in B. Then February 16 in C twice, 20th in C, March 5 in C, 7th in D and C, 9th in D, 13th in $\mathrm{D}, 14$ th in $\mathrm{D}$.

38162, Myrtle Warbler:

1916. Banded March 7, B station, taken March 9 in $B$ and $D, 10$ th in $B, 12$ th in $D, 13$ th in $C, 14$ th in $B, 15$ th in B and C.

1917. Another known for its trap habit in 1916 appeared the first day of trapping February 13 in $C$, then 14th in C, 15th in C twice, 16th in C twice, 20th in C, 23rd in C, 28th in C twice, and March 2 in C, $3 \mathrm{~d}$ in $C$ and $D, 7$ th in C, 8 th in $\mathrm{D}$.

38346, Myrtle Warbler:

1916. Banded March 14, and taken also March 17, at $\mathrm{C}$ and $\mathrm{B}$ stations.

1917. Taken Feb. 15 and 16 at C Station.

38175, Myrtle Warbler:

1916. Banded March 8.

1917. Taken Feb. 16.

38196, Yellow Palm Warbler (Dendroica palmarum bypochrysea):

1916. Banded March 9, B Station, and taken again March 12, C Station. 
Apr.

1931

1917. Taken Feb. 14, B Station.

These Warblers may remain through the winter, as they are present in numbers when I first arrive at Thomasville, in early February, but they increase in numbers about the middle of February; after March first very few Warblers are taken, and by March 15 all are gone except a few stragglers.

16481, White-throated Sparrow:

1915. Banded February 25, taken also Feb. 27 and March 1.

1917. Taken Feb. 22, 27, March 19, 20.

38443, White-throated Sparrow: (See figure 13).

1916. Banded March 29, taken also March 30.

1917. Taken Feb. 25, March 2, 4, 13, 15. Photographed on March 15.

38435, White-throated Sparrow:

1916. Banded March 27.

1917. Taken March 2 and 4.

38160, White-throated Sparrow:

1916. Banded March 5, taken also March 6, 7, and 16.

1917. Taken March 7 and 19.

38438, White-throated Sparrow:

1916. Banded March 27 and March 29.

1917. Taken March 7.

The White-throated Sparrows are always about Station A, the same spot as in 1915 and 1916, and it seems reasonable to call it the same group, coming each year with some accretions of the year (as I banded 18 new birds out of the group). This identification of the group as the same group is based upon the fact that in 1916 I obtained two 1915 birds, and this year I have had, as shown above, one 1915 bird and four 1916 birds.

These birds probably remain all winter, as they are settled at Station A when we go south, in early February, and they do not change location or move away before April. 
38313, Chipping Sparrow:

1916. Banded March 13. Taken also March 14 and 16.

1917. Taken March 3 and 20.

38439, Chipping Sparrow:

1916. Banded March 28. Taken also March 30.

1917. Taken March 8 in D, 16 in C, 18 in C, 19 in B, 20 in D, 21 in C, 26 in B and C.

15098, Chipping Sparrow:

1915. Banded March 18.

1917. Taken March 12.

38428, Chipping Sparrow:

1916. Banded March 21. Taken also March 29.

1917. Taken March 12.

38442, Chipping Sparrow:

1916. Banded March 29.

1917. Taken March 14.

38318, Chipping Sparrow:

1916. Banded March 13.

1917. Taken March 14.

38434, Chipping Sparrow:

1916. Banded March 26.

1917. Taken March 14.

38337, Chipping Sparrow:

1916. Banded March 14.

1917. Taken March 15.

17271, Chipping Sparrow:

1915. Banded March 19. Taken also March 26 and 28.

1917. Taken March 16.

17278, Chipping Sparrow:

1916. Banded March 19.

1917. Taken March 17 and 19.

38409, Chipping Sparrow:

1916. Banded March 16. Taken also March 21, 24, 25,28 . One swollen foot. 


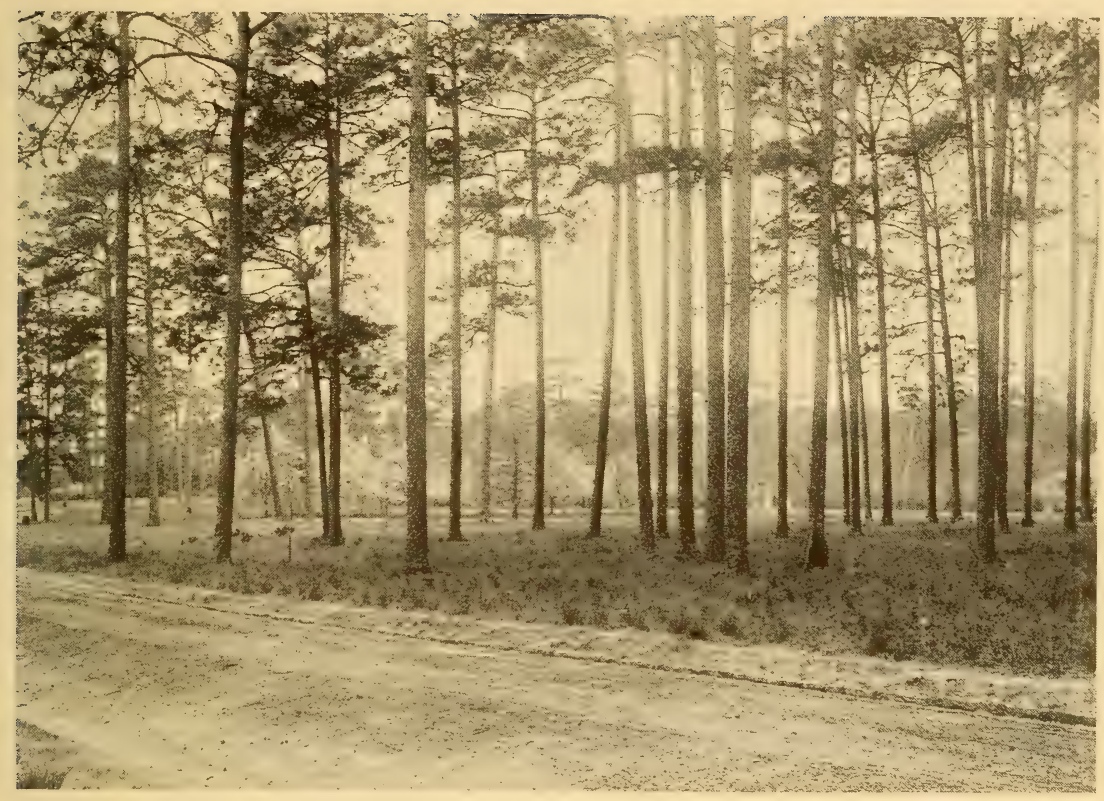

Fig. 9.-Inwood Plantation, Thomasville, Ga. Station A is at the House on the Left. Station B is Among the Pear Trees in the Center. Station C is at the Cottage on the Right. (See page [39].)

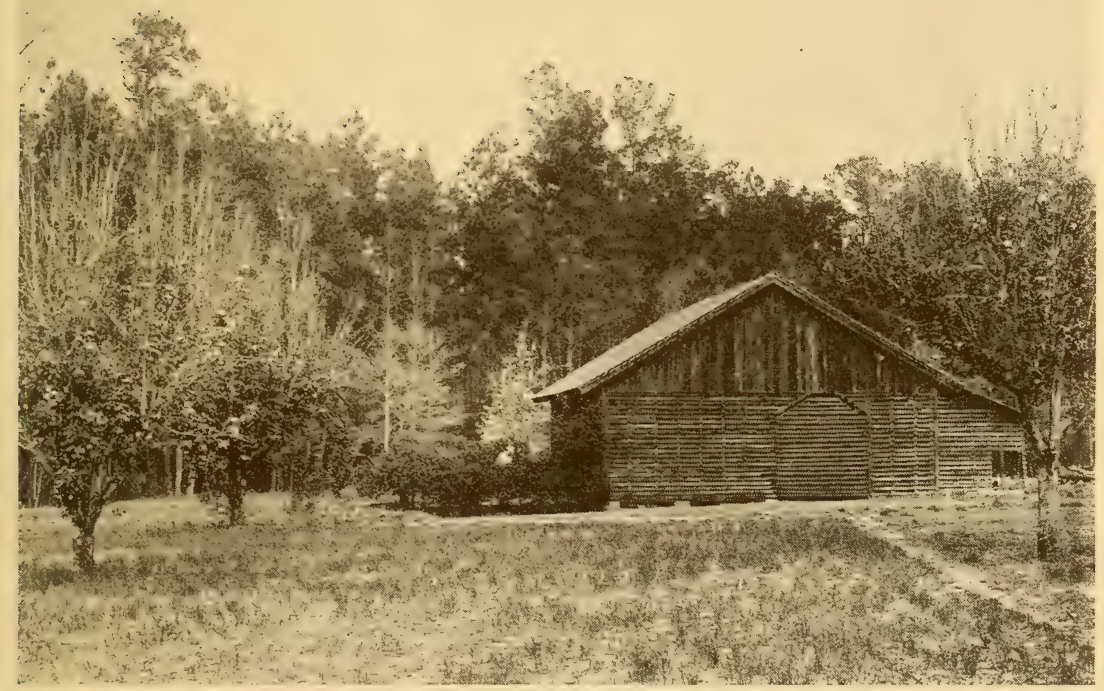

Fig. 10.-Station D, Thomasville, Ga. The Trap is Among the Shrubs but not Covered by Them. (See page [39].) 



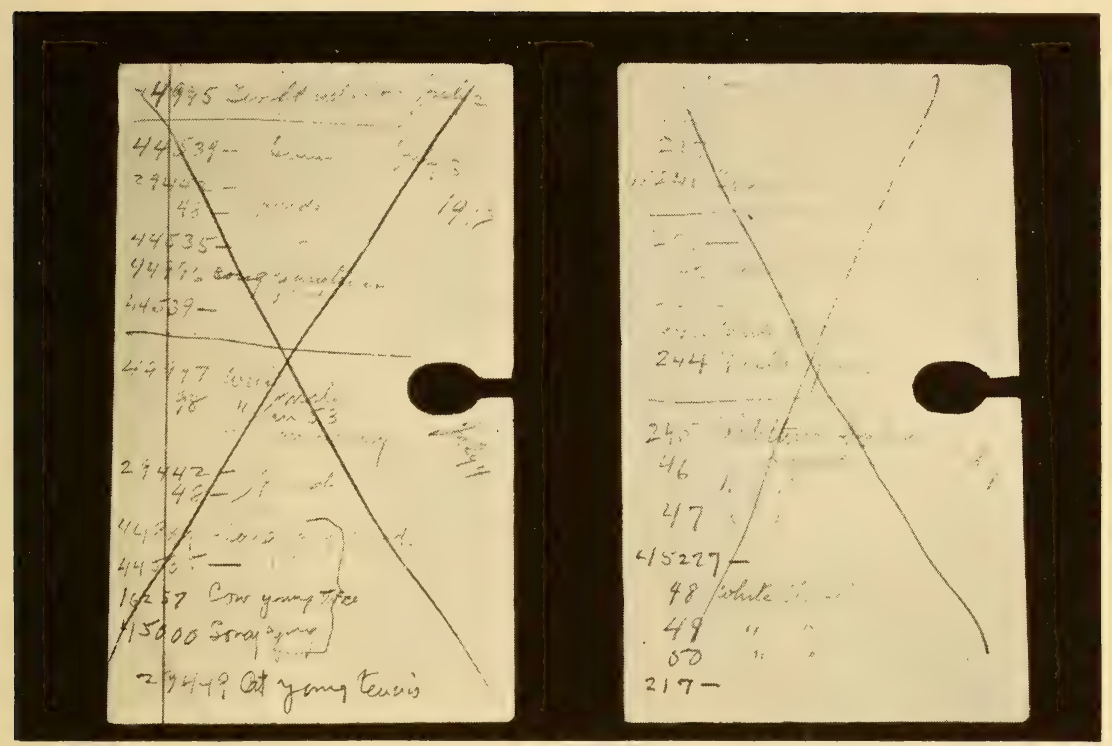

Fig. 11. - Type of Field Card Carried in the Banding Box. (See page [29].)

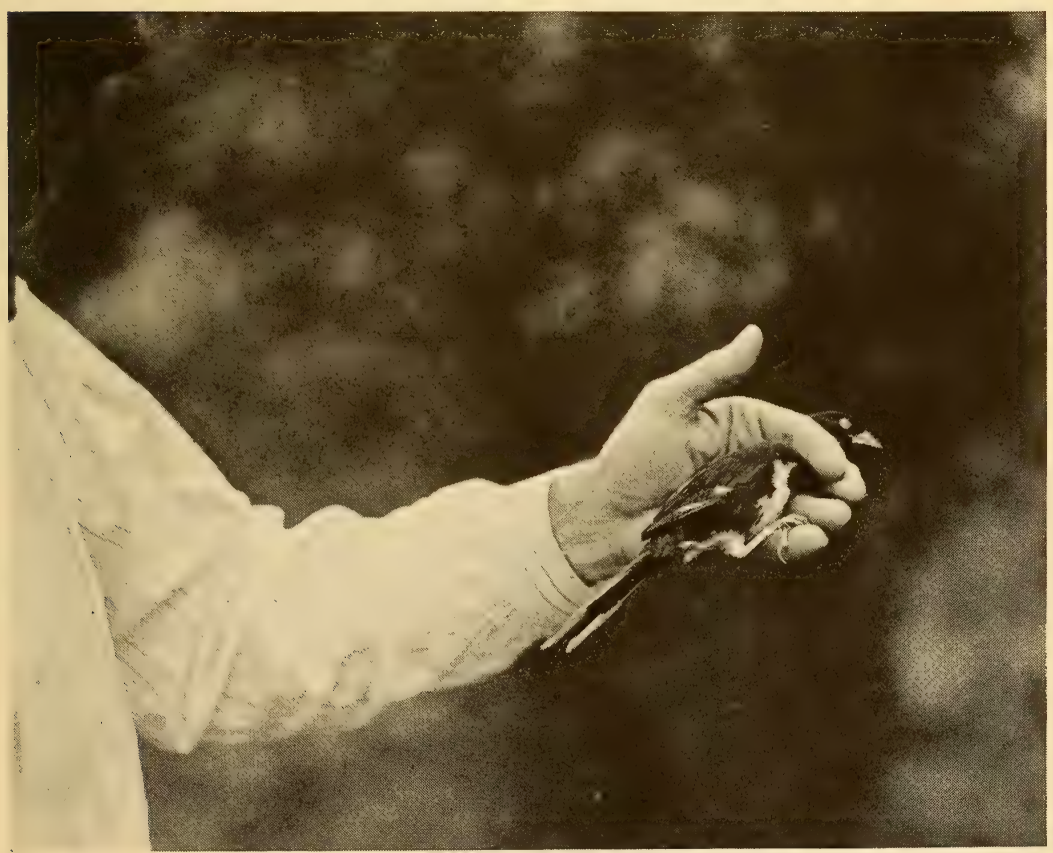

Fig. 12.-Number 31770, Towhee, Male. (See page [41].) 

Apr.

1931

1917. Taken March 19.

The Chipping Sparrows were not seen when we first came south in February; none was taken until March 3, when they appeared in great numbers. As they had evidently spent the winter farther south and were only stopping off at Thomasville, en route, on the migration northward, it seems remarkable that we should take, as shown above, three birds of 1915 banding, and as many as eight of 1916.

Among Chipping Sparrows we found again this year many birds having swollen toes, at least 10 , or probably 12 or 13 birds out of 128 , or about 10 per cent. of them.

Shrikes: We again had trouble with Loggerhead Shrikes, as they quickly learn to perch near a trap and kill any bird that is caught.

These birds are very abundant in Georgia and must destroy an enormous number of small birds. We are convinced that they do more harm than good and would favor a concerted attempt to destroy them.

\section{Sample Days at Thomasville}

The following are daily records taken from the field notes; every bird taken during the day is entered, the new birds receiving a band, and the birds that have already received bands this season marked "repeats" (see Fig. 11).

From these day-lists we compile for our convenience a sort of ledger-list upon which each successive occurrence of a bird is carried back to the original entry of that bird, thus giving concisely the history of each individual for the season, or for successive seasons. When banding on such a scale, we find these lists very convenient for quickly hunting up birds that are re-taken. 
1917:

February 13. Sunny $50^{\circ}$ Temp. Set traps A, B, and C.

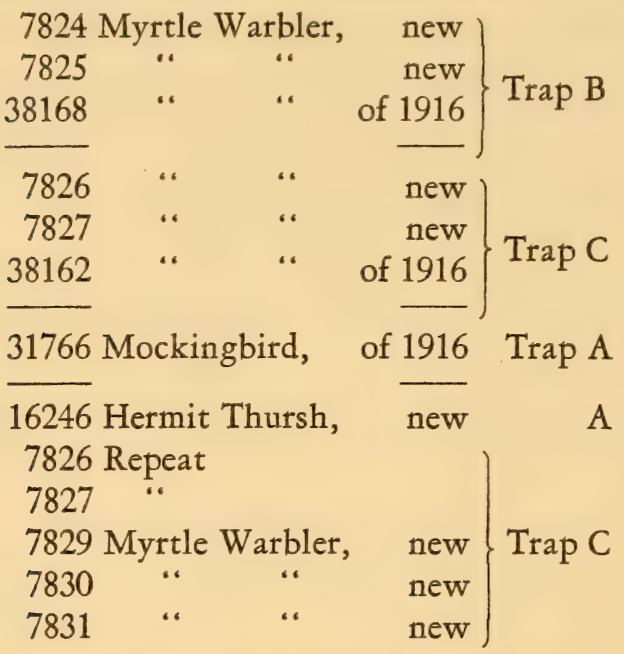

First Day of this Season-at Thomasville

March 3. Sun $75^{\circ}$. Traps A, AA, B, C, and D.

38313 Chipping Sparrow, of 1916

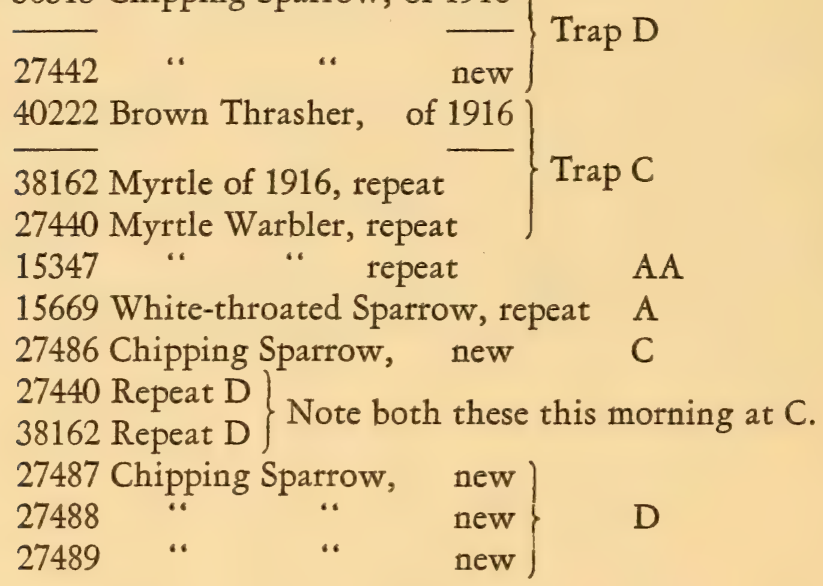

Today is First Appearance of Cbipping Sparrows 
Apr.

1931

March 12. Sun $70^{\circ}$. Traps A, AA, B, C, and D.

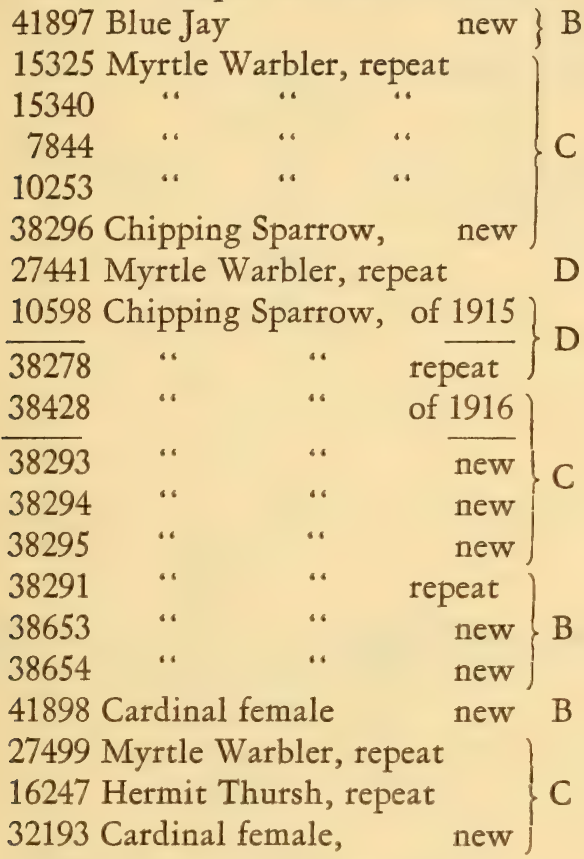

27442 Chipping Sparrow, repeat

27500 " " repeat, swollen right toe D 16251 Towhee female, repeat

31770 " male of 1916 , repeat A, taken together several times.

15669 White-throated Sparrow, repeat A 19247 Brown Thrasher of 1916, repeat AA

March 15. Sun $75^{\circ}$. Traps A, AA, B, C, D.

On this day the traps were not visited until 11 o'clock A.M., when the following birds were removed and photographs taken of some of them.

38665 White-throated Sparrow, new A

31770 Towhee male of 1916, a repeat, in AA (See Fig.12)

31779 Brown Thrasher of 1916, repeat D 
38271 White-throated Sparrow, repeat D: note station D, not $A$.

27496 Chipping Sparrow, repeat D 38337 " " of 1916 D

40222 Brown Thrasher of $\overline{1916}$ repeat C $\left.\begin{array}{lll}38664 & \text { Chipping Sparrow, repeat } \\ 38666 & \text {. }\end{array}\right\}$ new 38667 “ 30 new $\begin{array}{llll}38668 & \text { ". } & \text { " } & \text {." } \\ 38669 & \text { " } & \end{array}$ $\begin{array}{llll}38669 & \text {. } & \text {. } & \text {. } \\ 38670 & \text { " } & \text { “ } & \text { B }\end{array}$ 38670 38671 37500 38289 38658

31770 Towhee male )repeats in A, (Fig. 14) 31770 having 16251 " female been removed from AA only half an hour before.

38443 White-throated Sparrow of 1916, repeat A, (Fig. 13) 15345 “ “ “ $\quad$ " 38672 “ “ . . .

\section{Banding near Cleveleand, Ohio}

Season of 1914

During this season I became interested in banding, and from June 15 to November 1 banded 117 birds, mostly young birds in the nest, including six Yellow Warblers, 12 House Wrens, 6 Chipping Sparrows, 15 Catbirds, 14 Robins and a few Flickers, Song Sparrows and others. Not until October, when I began to trap the House Sparrows, did I begin to find out the value of trapping in the banding work.

Season of 1915

Banded from the nest. . . . . . . . . . . . . . . . . . . . . 135

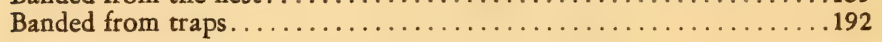

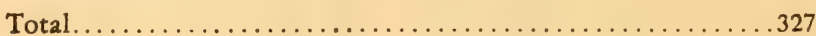


Apr.

1931

After my experience in Thomasville, Georgia, in March, 1915, I realized the importance of the traps, not only for banding adults but because of the immensely greater probability of getting returns. During the early part of the season the traps were out only occasionally, for a few hours, and this may partly explain why so few returns of birds banded in 1914 were obtained.

There were only two returns from last year:

15819, Catbird (Dumetella carolinensis), adult:

1914. Banded July 5, and taken July 6 and August 12 with young 17388 .

1915. Taken May 23.

15839, Song Sparrow (Melospiza melodia melodia):

1914. Banded October 6.

1915. Taken May 31.

The Catbird had, no doubt, been south for the winter and returned; but the Song Sparrow may have remained here over the winter.

The Divorced Wrens: It was during this season that I discovered that, in case of birds nesting in boxes, or holes in trees, as the Wrens, or Bluebirds, or Woodpeckers, it is quite easy to catch the adults, for banding, as they enter the nest to feed the young.

A pair of House Wrens, Nos. 27739 and 27740, in a box on the greenhouse, were banded in this way on June 19, 1915. Their brood, banded at the same time, received bands 27723 to 27728 inclusive. After an absence from the farm for six weeks I returned to find, in the same box on the greenhouse, another young brood just ready to fly. I gave them bands 27783 to 27787 inclusive, and caught the parents, to discover to my surprise that one parent was 27740 , but the other was a new mate, without band, and received band 27782. As birds so quickly find a new mate, when a mate is lost by death, I did not realize just what had happened until I found that 27739 had at the same time (August 14), a nest in a box only 100 feet away, with a new mate, and a brood ready to fly, 27772 to 27777 inclusive. I was unable to get this second 
mate of 27739 because the young left the nest that day, August 14.

No. 27739 has further distinguished itself by coming back, in June, 1916, to the same box occupied by it for its second brood in 1915, and I have marked the mate, but of course cannot tell whether it is the same as its second mate of 1915 . This 1916 mate of 27739 is No. 38491 and with this mate there were raised the young brood Nos. 38492 to 38496 inclusive.

Total Wrens banded in 1915-44.

All left the farm September 5 with the storm.

Song Sparrows: Total banded-88. Of the 20 banded in May and June, only one was taken after July, No. 27755, taken on October 1. During six weeks in July and early August, observations were omitted because of absence from the farm. During the last two weeks of August, 34 were banded, many young birds in family groups; and some of these were frequently re-taken until September 5. On September 4 and 5 , there was a drop in temperature accompanied by storms, and the families of Song Sparrows departed; only 4 birds were taken after September 5, No. 27781, a young bird, on September 22; No. 27800, on September 23 and 30; No. 27806, on September 27; and No. 27822, on October 17. A week after September 6, hardly a Song Sparrow was seen, then new birds began to come in; 26 banded in September and October.

All this means that after the first broods left the nests in June, both old and young left that vicinity; then other parents raised other broods in August and these mostly departed at the first September storm.

White-tbroated Sparrows: Total banded-43.

First appeared from the north on September 25, abundant by September 30 . The birds arriving and registered in September and the first week of October did not move on each day, but many of them remained there as long as weather and feed were good, to go, on October 15, when the next storm developed; with that storm came new individuals, who, in turn, remained through good weather and moved along at the time of the next storm, about October 26, when all disappeared. 
Apr.

White-crowned Sparrows: These did not appear until October 1 , and the early individuals, like the White-throated Sparrows, remained about the farm until the storm of October 14, some late arrivals remaining until the next storm on October 26, and a few stragglers until October 30.

Of the 28 individuals banded in October, only 7 were in mature plumage.

\section{Season of 1916-May 1 to November 1, Clevveland}

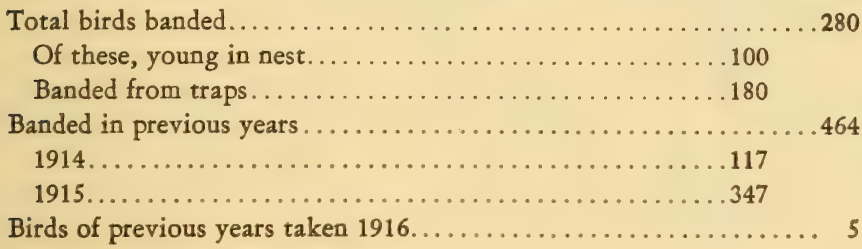

From these figures, it appears that 280 new birds were banded during the summer; that during the two previous seasons a total of 464 birds had received bands; and during the summer of 1916 only five birds were taken of the possible 464 which had received bands in previous years.

This seems to bear out the conclusion I came to after the season of 1915, that birds do not return to exactly the same spot from year to year nearly so much as they are popularly believed to return.

This conclusion is not wholly fair, however, as to the summer of 1916, because, for business and other reasons, I was unable to make the same systematic study as during the summer of 1915.

At no time during the summer could I operate the traps except occasional days, or parts of days, perhaps two or three times a week; then I was absent the entire months of July and August.

The five birds taken from 1915 birds were as follows:

27705, Song Sparrow:

1915. Banded May 26 and taken June 5.

1916. Taken June 20 on same spot.

1918. July 7, killed in trap by a Shrike. 
27844, Song Sparrow:

1915. Banded September 25.

1916. Taken September 19, on same spot.

27845, Song Sparrow:

1915. Banded September 26.

1916. Taken dead August 28.

31741, Red-headed Woodpecker (Melanerpes erytbrocepbalus), male:

1915. Banded June 19. Mate of 31739.

1916. May 22, shot in same orchard because he insisted upon appropriating a nest already occupied by a Bluebird family.

27739, House Wren (Troglodytes aedon aedon):

Most interesting, one of the so-called "divorced Wrens" of 1915. See this bird and 27740 of last year. Appeared this year and with a mate, 38491, had a brood, 38492 to 38496 inclusive in the same box which this bird occupied with its second mate of last year. As I was unable to catch and band the second mate of last year, I am unable to say whether this year's mate is the one taken as second mate last year.

This can be put down as a season of negative results, because of lack of time. During 1915 I had banded every House Wren, old or young, on the farm but could not watch them closely this season, so had only one return.

Wbite-crowned and White-tbroated Sparrows: In 1915 these came in distinct waves; with each storm the marked lot would depart, and a new lot come down from the north. In 1916, during the whole of September and October, a uniform condition of weather prevailed, at least the storm periods were not severe, and the effect was noticed in the scattering arrival and departure of these Sparrows.

White-crowned Sparrow: banded 15, of this number 12 in immature plumage, all migrating.

Song Sparrow: banded 68, very few being retaken, but again this was due to the traps, being out so little during the season. 
Sci. Pub. C. M. N. H.

Vol. I, Plate XXV

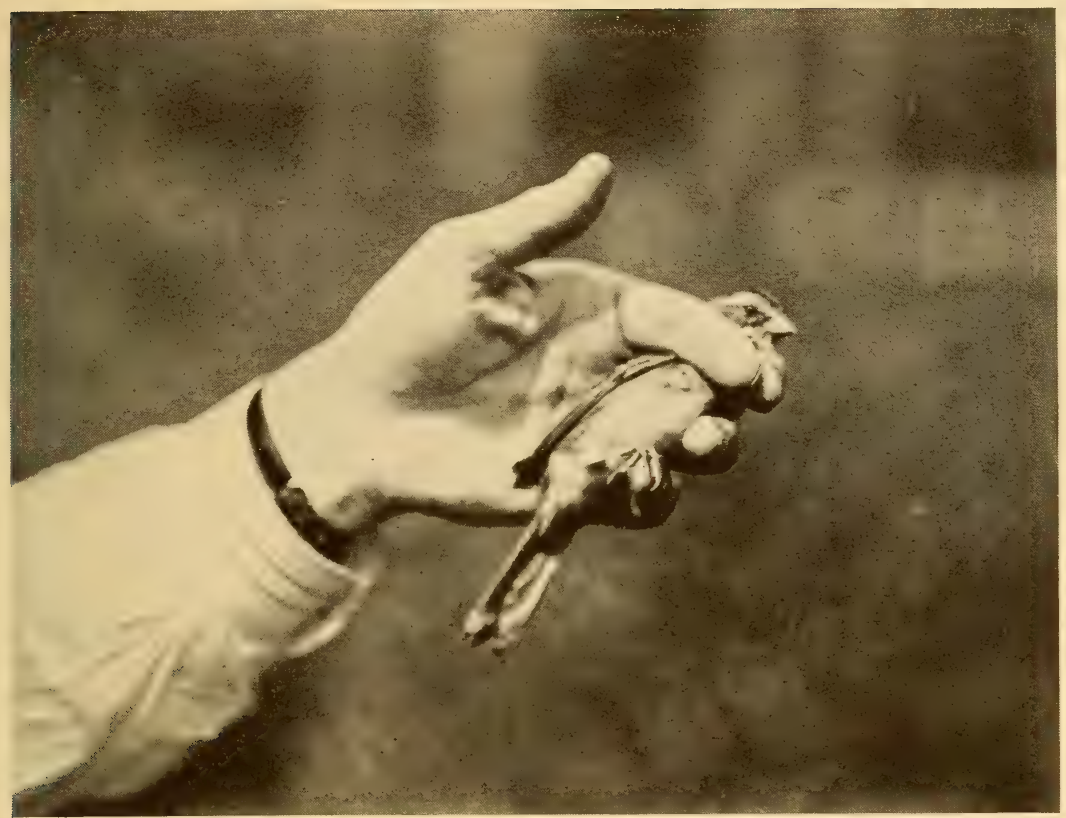

Fig. 13.-Number 38443, White-throated Sparrow. (See page [43].)

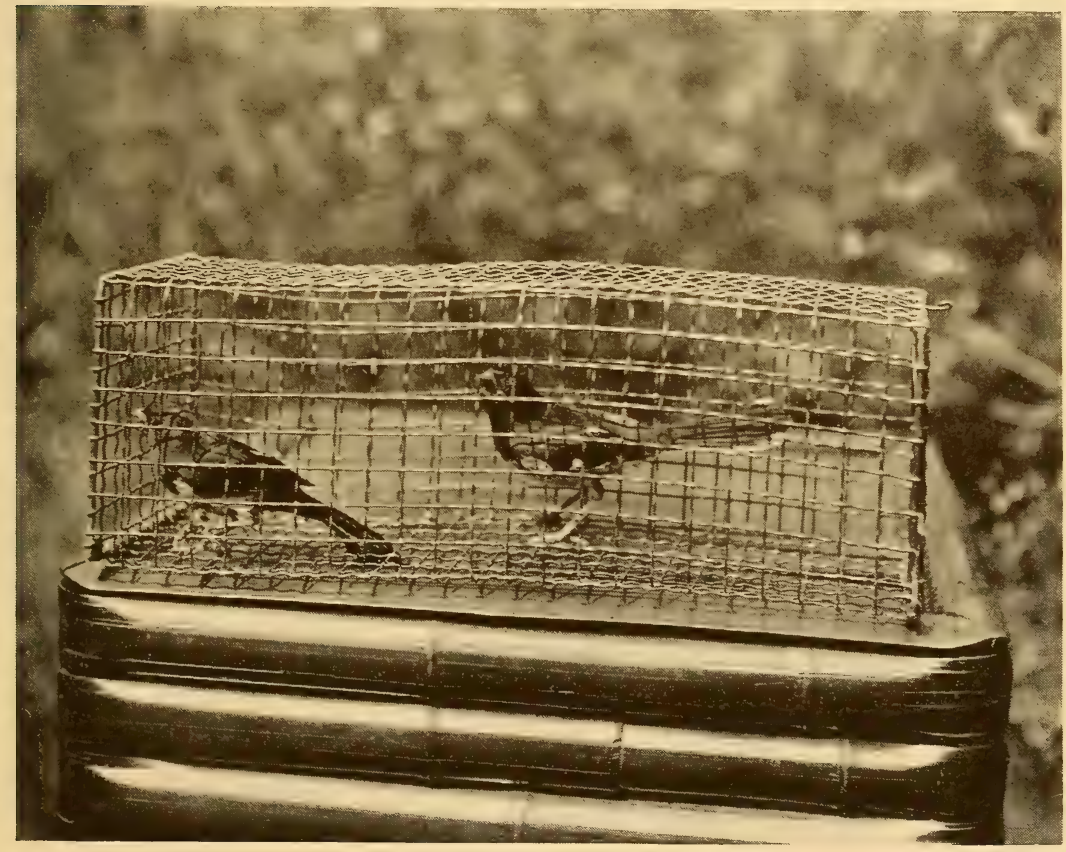

Fig. 14.-A Pair of Towhees. (See page [48].)

Nos. 31770 and 16251 

Apr.

1931

Junco: banded 8 birds, and not before October 13, after the White-crowned and White-throated Sparrows had mostly gone.

Other birds taken in the traps are Field Sparrows (Spizella pusilla pusilla) and Chipping Sparrows, with an occasional Catbird or Brown Thrasher.

I wish to call attention again to the very great increase in the number of native birds of all kinds about my farm during the last three years since I have operated sparrow traps more or less steadily all year, and thus kept the farm free of House Sparrows.

\section{Season of 1917, Clevveland}

New birds banded -167

Returns from previous years:

38645, Song Sparrow:

1916. Banded Sept. 14.

1917. Taken May 11.

38480, Song Sparrow:

1916. Banded June 18, and taken June 20.

1917. Taken May 15 and July 15.

38461, Chimney Swift (Cbaetura pelagica):

1916. Banded June 6.

1917. Taken June 12. In both cases it came down same bedroom chimney.

29867, Catbird:

1916. Banded June 25.

1917. Taken June 21 and 23 and on June 24 with 16254. Killed in trap by hawk June 24, 1917.

29863, Catbird:

1916. Banded June 22.

1917. Taken June 21.

1919. Taken June 21, tail missing.

1924, Brown Thrasher:

1916. Banded June 27; described as a brilliant bird.

1917. Taken July 3, with young, 20584, 40790, 21525, 21526. 
1918. Taken June 22, with young, 53026, 53027, 53028, and June 24 and 27.

31733, Northern Flicker (Colaptes auratus luteus):

1915. Banded June 3.

1917. Found dead May 15.

White-crowned and White-throated Sparrows: For some reason the White-crowned Sparrows have, this autumn, far out-numbered the White-throated, quite contrary to my usual experience here.

This October the migration of these two species has been in waves, again, as in 1915, arriving and departing with the storms.

They came in about October first, then numbers of them left about the 11 th when the temperature dropped, and a trace of snow fell; many new ones came down from the north at the same time.

Then on October 20 there was another fall of temperature and snow-fall, and more of these birds went South. They all left at the time of the blizzard of November first. Because it is difficult to operate the traps during a storm, and because the birds do not feed at such times, it is not easy to say whether birds leave ahead of a storm, during the storm or after it; but certainly many of them do feed at the traps right up to the time of the beginning of the storm period.

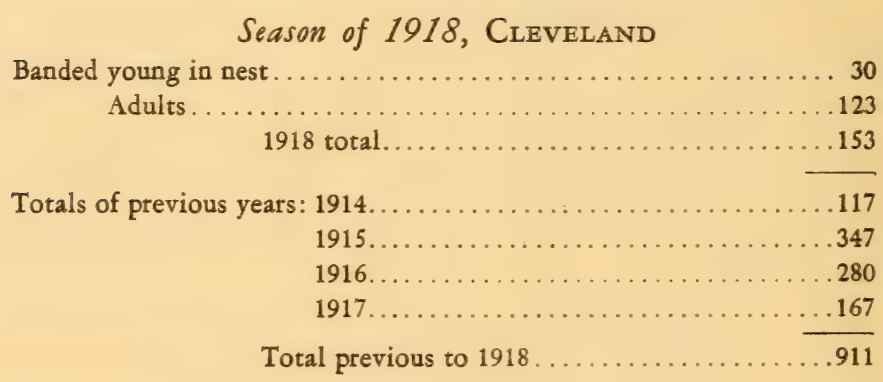

Returns from previous years: 44008, House Wren:

1917. Banded July 4 with mate 44009 and brood 44010 to 44014 inclusive. 
Apr.

1931

1918. Taken June 19 in the same nest box No. 51 in the corner of the flower garden. New mate of this year 44100 . Brood with this mate 44508 to 44514 inclusive.

1924, Brown Thrasher:

See 1917 list for the history of this bird for three years, and its young of two seasons.

44018, Song Sparrow:

1917. Banded July 4 and then marked young.

1918. Taken June 23.

Since the question is asked whether young birds will return to the same spot another year, it may be best to say that this was not banded in the nest, but was banded with three others taken from the trap at the same time and all judged by appearance to be young of the same brood. There is of course the possible error of judgment of the age under the circumstances.

40241, Robin (Planesticus migratorius migratorius):

1916. Banded May 28, young in the nest.

1917. March 3, taken at Langley, South Carolina, on the farm of Mr. S. C. Holman; "found wounded" by Mr. Holman's young son.

21531, Sparrow Hawk (Falco sparverius sparverius):

1916. Banded June 18, young in the nest.

1917. July 12, shot by Roy Haylor, near Engine Co. No. 11, East 91st Street and Walker Ave., Cleveland.

Additional data: In letter dated Aug. 9, 1917, Mr. Haylor says, in answer to questions: "For the last few years this same hawk, as we think, has sat on the tip of a church steeple for hours each day, and this church is in a small park which is a nesting place for lots of robins and other birds. This hawk would rob the nests and eat all the young, so we decided to shoot him, as the birds were in commotion whenever he was around. 
"He used to roost at night in the top of the steeple till a pair of yellow hammers made their nest up there two years ago. Then he went somewhere else at night. We have never noticed a mate, but the next day a hawk of the same kind soared around, and has ever since, as though it was looking for him, but he never alights on the steeple."

27705, Song Sparrow:

This bird taken in 1915, 1916, and 1918.

For dates see 1916 list.

32932, Robin:

1917. Banded May 15, young in the nest.

1919. Taken March 19.

This, properly belonging to the experiences of this current year (1919), is included, as it appeared in the greenhouse, the first bird taken this season. And here is an absolutely certain case of a young bird returning to the spot where it was hatched. No doubt it was on the place in 1918 but I have, as yet, no practical way of getting Robins by trap.

\section{Notes in 1918.}

Baltimore Oriole: One family of Orioles (Icterus galbula) learned to come to the trap the day the young left the nest, and came several times a day for a few days, then disappeared. Orioles had never come to the bait before.

White-throated and White-crowned Sparrows: For some unknown reason, last October the White-crowned Sparrows greatly predominated, while this year the White-crowned were hardly to be seen. Banded 44 White-throated and only 3 White-crowned. White-throat, No. 45245 , was marked as a bird of extra fine plumage and an extra fine squealer when handled. The migration of these birds has been this year like that of 1916. Uniform mild weather without severe storms has given little cause for the birds to come and go in waves as in 1915 and 1917. 
Apr.

1931 BaLdwin-Bird Banding By Trapping

THE MARRIAGE RELATIONS OF THE HOUSE WREN (TROGLODYTES A. AEDON).

BY

S. Prentiss Baldwin

INTRODUCTION

The belief that most birds mate for life and each year return to the site of the previous nest to rear their young, is very old, and in the popular mind it is probably more or less generally accepted. The following data will have a bearing on this matter 
and will also throw additional light on the interesting subject of incubation periods.

It was in the spring of 1915 that I began the use of trap nest boxes and numbered bands for the house wrens on my farm near Cleveland, Ohio, and made the interesting discovery of my first 'wren divorce'.' This pair, having successfully raised one brood together, separated, and each secured a new mate for the second brood of the same season. The question that was immediately presented by this action was: is this exceptional or is it a matter of regular occurrence with this species?

Since then I have used increasing care to take the adults of each season and to band both them and their young, with the result that my suggested need of a genealogical tree, seems warranted. When it is realized that in one case, I have an accurate record from the original parent stock to the third generation in direct line, with numerous uncles, aunts, cousins, brothers and sisters, it is apparent that the services of a trained genealogist may be needed to continue the record.

In trapping the occupants of my nest boxes, I have found it advisable to wait until the adults are actively engaged in bringing food to the young. There is then no question as to the mates for the nest under observation and there is less danger of the birds' deserting. I have at times trapped one or both adults before the eggs were hatched or even laid, but they will almost invariably abandon the nest if interfered with at that time. I have also found it advisable to carry an account with the nest boxes since the resulting data provide interesting information relative to incubation periods and time from hatching to flight, as well as the choice of the birds for the different locations of the nest boxes.

In the paper previously referred to, I gave a summary of the first "wren divorce case" that came to my attention. In the following paragraphs this case is reviewed in addition to the family histories of four additional cases that I have studied. Although the term "divorce" may not be just the technical word that fits the case, their apparent love of change in marriage relations seems fully to justify its use. It has been suggested that poly-

2 'Bird Banding by Means of Systematic Trapping' S. Prentiss Baldwin, Abstract Proc. Linn. Soc. of N. Y., No. 31, 1919, p. 49. 
Apr.

gamy may enter into the consideration and that two families may be raised at once, but if this is ever true, there has been no evidence of it among the wrens that have been under my observation.

The "A" Group.

My first case was provided by the pair of wrens that carried bands numbered 27739 and 27740 and reared their brood in box No. 9 on the greenhouse. These birds were banded on June 19, 1915 , and after the young had flown I was absent from the farm for about six weeks. Upon my return on August 15, I was surprised to find another brood in this same box ready to fly. When the adults were trapped I was further surprised to find that while one parent was No. 27740 , the other was unbanded. I gave this new mate band No. 27782 presuming at the time that No. 27739 had met with an accident.

But upon making the rounds of the other boxes I discovered that instead of being a casualty, this bird was the proud father (or mother) of another brood by another mate in a box only 100 feet distant on the pumphouse. I was unable to capture this mate but it was not a banded bird. Here was a clear case of divorce, both birds remating with new mates and raising second broods the same season.

Number 27740 has not been heard from since, but the following year (June 23, 1916) No. 27739 was back in the box on the pumphouse where its second brood of 1915 had been raised. This year I succeeded in trapping the mate, banding it as No. 38491, but I do not, of course, know whether or not this was the second mate of 1915.

\section{The "B" Group.}

On July 4, 1917, box No. 51, in the east garden was occupied by Nos. 44008,44009 , and their brood. Neither of these birds raised a second brood during that season (at least they did not occupy any of my boxes) but on June 19, 1918, No. 44008 was back at the same box, with a different mate, No. 44100 . The next year (June 17, 1919) box No. 19 on the greenhouse was occupied by these two, this being my first record of a pair of wrens that have either remained mated or have returned and remated after one season. This box is located about 200 feet from No. 51 
where the 1917 and 1918 broods were raised. The broods of 1918 and 1919 were therefore full blood brothers and sisters although only step-brothers and sisters to the brood of 1917. No record of any of this family in 1920 .

\section{The "C" Group.}

Box No. 25 on the laundry was occupied June 17, 1919, by numbers 45302 and 45303 . The brood was raised and No. 45302 then disappeared, but its mate, No. 45303 , mated again and on July 10 was busily engaged in the rearing of a second brood in box No. 53, on the library, with a mate that was numbered 45349 . For No. 45303 we thus have for this season a second mate and a second brood in a different box.

In 1920 (June 17) 45303 again returned and again started nestbuilding in box No. 25 on the laundry where the first brood of 1919 was raised. The mate this year was No. 45342 , which had a curious history with 45335 and 45349 in 1919 . He, 45342, had settled alone in box No. 53 on the library, on June 26, 1919, where he sang and carried on nest building by himself until driven out by 45349 and 45335 . On July 29, 1920, this pair (45303 and 45342) were raising their second brood for the season, in the same box. The total record for No. 45303 is therefore; four broods in two years, or 27 young; with three mates. Three of the broods were raised in the same box. It should be further noted that in 1920 there was no divorce, as both broods were by the same mates, and in the same box.

Going back now to No.45349, the second mate of 45303, and we have a little of his earlier history. He was taken on July 4, 1919, in box 53 on the library with 45335 . These two were seen together just this one day but they seemed to be busily engaged in nest building. Number 45335 had been mated with No. 45334 in box 63 on the woodshed and their brood had left the nest only two days previous. This was apparently, only a flirtation, however, as 45349 finally mated with 45303 (as above) in this box and raised a brood of seven youngsters.

In 1920 , No. 45349 , the second mate of 45303 in 1919 , selected a new mate, No. 46006 , and proceeded to nest in box No. 47 on the garage. Thus 45349 and 45303 , who were mates for the second brood of 1919, both appear in 1920 with new mates. 
Apr.

The " $D$ " Group.

This family history started on July 14, 1918, when I banded numbers 45205 and 45206 at their nest in box No.47 on the garage. The brood was not banded. Nothing more from this pair during 1918 and 45205 drops entirely from sight, but in 1919 (June 17) I found that 45206 had returned with a new mate, given band 45311 , and was nesting in box No. 26 in the sugar house. After this brood had flown 45311 took a second partner No. 45324, and proceeded to nest in box No. 6 on the upper barn. This was on August 5, and as this second mate of 45311 was banded, I referred to my records to learn that it had already raised one brood that year (banded June 19) with No. 45332 in box No. 3 on the farmhouse.

This latter case (45324 and 45332) was the start of an interesting genealogical tree. They were banded in box No. 3 on June 19,1919 , their brood receiving numbers 45325 to 45331 . On June 22, 1920, I took and banded (No. 45968) a bird in box 53 on the library, where it had evidently been nest building alone, singing constantly. On July 5 a mate appeared which I captured on the 7 th and my delight may be imagined when I found it was No. 45325 , one of the 1919 brood of 45324 and 45332 raised in box No. 3 on the farmhouse.

These birds now moved around to the other side of the house to box No. 59, probably because I caught and handled them at No. 53 before the home ties were cemented by eggs and young. On July 27 their young were hatched and were later given bands No. 46074 to 46079 . These young were therefore the grandchildren of numbers 45324 and 45332 .

\section{The "E" Group}

In the case of numbers 45334 and 45335 , that started my record of the " $E$ " family, there were strong indications of a serious flirtation as well as some unquestioned divorces. This pair nested in box No. 63 on the woodshed and were banded, together with their brood, on June 25, 1919. On July 4, just two days after their young had flown, No. 45335 was taken with No. 45349 in box No. 43 on the library (See " C" Family) where, after routing out No. 45342 , who had been in solitary possession, they 
engaged in active nest building for a day or two. The nest was then abandoned and it may be that 45335 returned to his former mate, No. 45334 , in box No. 30 on the ice-house. This latter bird, with its mate, raised a second brood, the first having been in No. 63. I regret that I was unable to capture the mate, since if it was No. 45335 , it would prove the suggestion of a flirtation.

Number 45335 returned in 1920 with a new mate, given number 45955 , and a brood was raised in box No. 49 in the garden and banded on June 15. Following this they were divorced and with new mates they both proceeded to the raising of their second broods. Number 45335 mated with 45988 (new) and raised a second brood in box No. 63 on the woodshed, while No. 45955 mated with No. 46032 (also new) and nested in box No. 37 on the cottage. Thus after the divorce, both of the original pair secured new mates and raised second broods in the same season. Number 45335 has made a record of four broods in two seasons with at least three and possibly four mates, i. e. in case the first year's affair was only a flirtation. The second year it was a clear divorce.

It is interesting to note that in many cases, the second mates have been 'new' birds, i. e. they had not been recorded from my territory before, which would indicate that there must be considerable trading back and forth between different areas. In some other region, possibly close by my farm, there may have been several of my banded birds raising broods with mates that later moved over to my district and remated for the second brood. Such a theory could probably be proved if a well coordinated system were established. This might also explain what has become of the large number of young that I have banded, for, it will be seen from the foregoing account, only one of the young raised in my boxes has returned to nest in a succeeding season.

The successive matings of the birds in these five groups may be tabulated as follows in order to give a clearer idea of their complicated relationships. The first and second broods in each year are denoted by " $a$ " and " $b$ " after the year, while the " $x$ " between two numbers indicates that the two birds represented by those numbers were paired. The device in Group " $\mathrm{D}$ " denotes that 45325 was the offspring of the 1919 pair with which it is connected. 


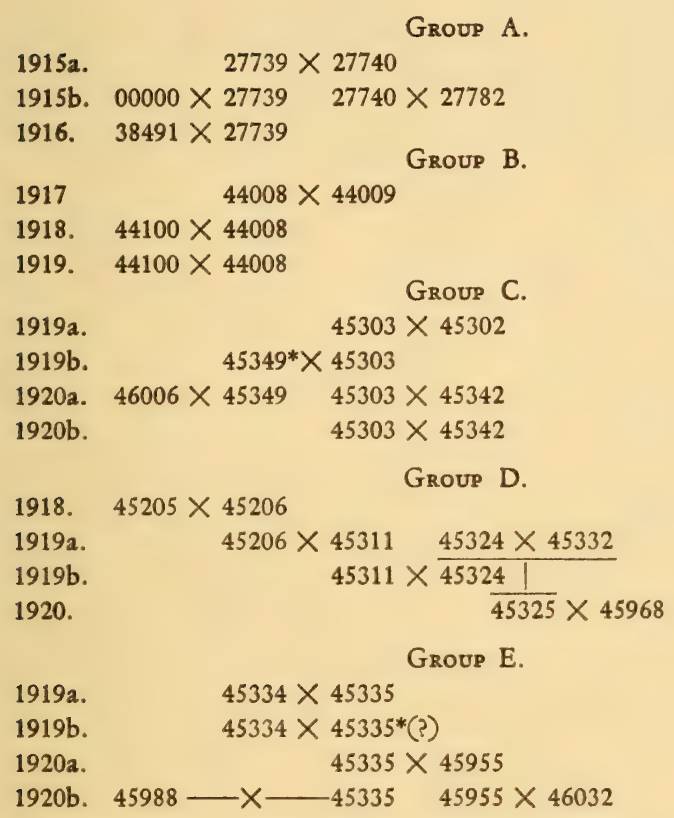

In keeping an account with each nest box, I have also secured some interesting information relative to the incubation periods, length of time from hatching to flight, and various idiosyncrasies of these birds. For the sake of those who are interested in such data this is presented in the following table. I regret that it is not complete for all cases.

\begin{tabular}{|c|c|c|c|c|c|}
\hline $\begin{array}{c}\text { Box } \\
\text { NuMBER }\end{array}$ & $\underset{\text { StARTED }}{\text { Nest }}$ & $\begin{array}{c}\text { NEST } \\
\text { COMPLETBD }\end{array}$ & $\begin{array}{c}\text { Set } \\
\text { CoMpLeted }\end{array}$ & $\begin{array}{c}\text { EGGS } \\
\text { HATCH }\end{array}$ & $\begin{array}{l}\text { Youno } \\
\text { LaAvB }\end{array}$ \\
\hline 6 & - & - & July 4 (5) & July 13 & July 28 \\
\hline 23 & July 4 & No progress & y July 23 and & the nest & removed. $\uparrow$ \\
\hline 25 & July 4 & July 6 & July 13 & July 26 & Aug. 10 \\
\hline 37 & - & - & July 6 (6) & July 20 & - \\
\hline 47 & - & - & July 7 & July 19 & - \\
\hline 59 & July 4 & - & July 15 (6) & July 27 & Aug. 12 \\
\hline 63 & - & - & - & July 3 & July 20 \\
\hline
\end{tabular}

* Just prior to pairing with 45303,45349 was nest building for one day with 45335 , but both abandoned the partnership. It is thought that the latter mated again with 45334 but this is not proven.

$\uparrow$ This box is near No. 25 and the nest was apparently built by the occupants of No. 25 as a diversion, or in the same manner that marsh wrens build their dummy nests. The building instinct seems to need exercise in some cases, while the mate is incubating. 
Sci. Pub. 168 The Cleveland Museum of Natural History Vol. I

From the above data, I conclude that the incubation period is usually about 13 or 14 days; and the period from hatching to leaving the nest, not less than two weeks, generally longer. 


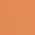

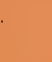




